\title{
The potential role of necroptosis in clinical diseases (Review)
}

\author{
WENLI DAI ${ }^{1 *}, \mathrm{JIN} \mathrm{CHENG}^{1 *}, \mathrm{XI} \mathrm{LENG}^{2}, \mathrm{XIAOQING} \mathrm{HU}{ }^{1}$ and YINGFANG AO ${ }^{1}$ \\ ${ }^{1}$ Institute of Sports Medicine, Beijing Key Laboratory of Sports Injuries, Peking University Third Hospital, \\ Beijing 100191; ${ }^{2}$ Medical Imaging Center, The First Affiliated Hospital of Guangzhou University \\ of Chinese Medicine, Guangzhou, Guangdong 510405, P.R. China
}

Received November 19, 2020; Accepted March 8, 2021

DOI: $10.3892 / \mathrm{ijmm} .2021 .4922$

\begin{abstract}
As an important type of programmed cell death in addition to apoptosis, necroptosis occurs in a variety of pathophysiological processes, including infections, liver diseases, kidney injury, neurodegenerative diseases, cardiovascular diseases, and human tumors. It can be triggered by a variety of factors, such as tumor necrosis factor receptor and Toll-like receptor families, intracellular DNA and RNA sensors, and interferon, and is mainly mediated by receptor-interacting protein kinase 1 (RIP1), RIP3, and mixed lineage kinase domain-like protein. A better understanding of the mechanism of necroptosis may be useful in the development of novel drugs for necroptosis-related diseases. In this review, the focus is on the molecular mechanisms of necroptosis, exploring the role of necroptosis in different pathologies, discussing their potential as a novel therapeutic target for disease therapy, and providing suggestions for further study in this area.
\end{abstract}

\section{Contents}

1. Introduction

2. Overview of the molecular mechanism of necroptosis

3. Difference of the key characteristics between apoptosis and necroptosis

4. Identification of necroptosis

5. Potential role of necroptosis in clinical diseases

6. Drugs and agents that regulate necroptosis

7. Conclusions and perspectives

Correspondence to: Professor Yingfang Ao or Dr Xiaoqing Hu, Institute of Sports Medicine, Beijing Key Laboratory of Sports Injuries, Peking University Third Hospital, 49 North Garden Road, Haidian, Beijing 100191, P.R. China

E-mail: aoyingfang@126.com

E-mail: xiaoqinghubj@163.com

${ }^{*}$ Contributed equally

Key words: necroptosis, cell death, mechanism, physiological function, clinical diseases

\section{Introduction}

Necroptosis, an emerging field closely related to apoptosis, is a non-caspase-dependent cell death that has been implicated in the pathological processes of various diseases. It is regulated by various genes that cause regular and ordered cell death. Through activating specific death signaling pathways, it shares typical characteristics of necrosis, including loss of metabolic function and subcellular changes $(1,2)$. Receptor-interacting protein kinase 1 (RIP1) was the first signaling molecule identified in the necrosome (3). RIP1 and RIP3 interact with the receptor protein, transducing death signals, and further recruiting and phosphorylating mixed lineage kinase domain-like protein (MLKL) (4-7). Necroptosis can be involved in the regulation of several signaling pathways, including the caspase-8-dependent apoptotic pathway, the mitogen-activated protein (MAP) kinase cascade, and activation of the nuclear factor- $\kappa \mathrm{B}(\mathrm{NF}-\kappa \mathrm{B})$ pathway.

To explore the potential role of necroptosis in human diseases, researchers have developed various methods, such as gene knockdown and knockout, and pharmacological inhibitors. By using these methods, it has been found that necroptosis plays an important role in pathophysiological processes of several clinical diseases, including infections, liver diseases, kidney injury, neurodegenerative diseases, cardiovascular diseases, and human tumors (8). In the current review, we aimed to explore the potential role of necroptosis in various clinical diseases.

\section{Overview of the molecular mechanism of necroptosis}

Necroptosis can be triggered by a variety of factors, such as tumor necrosis factor receptor (TNFR) and toll-like receptor (TLR) families, intracellular DNA and RNA sensors, and interferon (IFN) (9-11). TNF-dependent TNFR1 stimulation has three consequences that depend on the assembly of regulatory proteins. These different pathways ultimately stimulated $\mathrm{NF}-\kappa \mathrm{B}$-dependent inflammation, caspase-8-dependent apoptosis, or selective activation of necroptosis under caspase- 8 inhibition (Fig. 1) (12). TNF-dependent necroptosis is regulated by RIP1 and RIP3, which interact through unique RIP homotypic-interacting motifs (RHIMs) (Fig. 2) (13,14).

The interaction of RIP1 and RIP3 results in autophosphorylation, transphosphorylation, and assembly of 'necrosome' complex (5). RIP3 and MLKL are essential for necroptosis, whereas RIP1 is only sometimes involved in this process. 
RIP3 and MLKL knockout mice do not show deficiency in embryogenesis, homeostasis and development, indicating the role of necroptosis may be not essential in non-challenged conditions $(15,16)$.

\section{Difference of the key characteristics between apoptosis and necroptosis}

Although necroptosis is characterized by caspase independence, the molecular pathway involved is similar to and shares features of apoptosis. However, the immunological and morphological consequences of necroptosis are vastly different (Fig. 3). Necroptosis shares the major morphological features of necrosis, such as the swelling of organelles, gradually translucent cytoplasm, and rupture of the cellular membrane (12). By contrast, apoptosis is characterized by membrane blebbing, cell shrinkage, nuclear fragmentation, and chromatin concentration (17). The rupture of the cellular membrane results in the release of cellular contents, leading to the exposure of damage-associated molecular patterns (DAMPs), triggering a strong inflammatory response in necroptosis, suggesting necroptotic cells are more immunogenic than apoptotic cells, which is relatively intact, with DAMP restricted to the plasma membrane, or encapsulated in the apoptotic bodies (17). It has also been shown that necroptosis was associated with maintenance of T-cell homeostasis, as it has been found to be able to clear excess and abnormal $\mathrm{T}$ cells in the absence of caspase- 8 (18), which can prevent abnormal proliferation of lymphocytes (19).

\section{Identification of necroptosis}

As there is currently no specific marker for necroptosis, multiple methods are usually required to identify necroptosis (Fig. 4). In cultured cells, transmission electron microscopy can be used to identify necroptotic cells (20). Detection of key molecular, including RIP1, RIP3 and MLKL activation, necrosome formation, MLKL oligomerization, and membrane translocation can also be used to identify necroptosis (21). Activation of RIP3 and MLKL can be monitored by western blot analysis to assess phosphorylation status $(22,23)$. Phosphorylation of MLKL at Ser358 and Thr357 and RIP3 at S227 indicates the activation of necroptosis (24). In particular, MLKL phosphorylation has been used as a biomarker for certain disease diagnosis and prognosis (25). In addition, several pharmacological inhibitors such as the necrostatin (Nec)-1, GSK872, and necrosulfonamide (NSA) have also been used to detect necroptosis $(7,26)$. In vivo, the activation of necroptosis can be identified by the elevated levels of RIP1, RIP3, or MLKL mRNA or protein. Additionally, previous findings suggested that RIP3 and MLKL are more specific molecular biomarkers than RIP1 for the detection of necroptosis (27).

\section{Potential role of necroptosis in clinical diseases}

Physiological functions. Over the last decade, researchers have put a lot of effort into the development of effective RIP1, RIP3, and MLKL inhibitors, and created mouse models that lack one or more components of the necroptotic pathway at systemic level or in specific tissues (28). Due to the existence of these models, the physiological function of proteins of necroptosis have been investigated. Conditional deletion of RIP1 in keratinocytes or intestinal epithelial cells suggested RIP1 plays an essential role in maintaining epithelial homeostasis $(29,30)$. It is worth noting that the role of RIP1 in maintaining the intestinal barrier is similar to caspase-8 (31). In addition, mice with Birc2, Birc3, and Xiap codeletion in the myeloid lineage have high levels of circulating inflammatory cytokines, sterile inflammation, and granulocytes, which can be partially corrected by the lack of RIP1 or RIP3 (32). Tamoxifen-induced systemic RIPI gene knockout in adult mice is fatal due to a surge in cell death and intestinal bone marrow failure, which accumulates and causes fatal systemic inflammation $(33,34)$. Fetal hepatocytes that received tamoxifen-induced RIP1 deletion or RIP1 $1^{-1-}$ progenitor cells are unable to repopulate irradiated receptors. This defect can be partially corrected by the concomitant lack of RIP3, indicating that RIP1 plays a key role in the survival of hematopoietic stem and progenitor cells $(33,34)$. Furthermore, systemic inflammation caused by $R I P 1^{-1-}$ can be restricted in $R I P 1^{--}$RIP $^{--}{ }^{-C}$ Casp $8^{-/}$hosts $(34,35)$. These hosts show age-related lymphoproliferative disorders similar to those developed by $R I P 3^{--}$Casp $^{-/-}$mice $(11,34,36)$. In addition, compared to control animals, $R I P I^{+/-}$mice, mice treated with intravenous siRNA targeting RIP1, and Nec-1-treated mice showed a higher rate of physiological intestinal epithelial cell regeneration in the small intestine (37). In addition, the negative effects of Nec-1 on the regeneration of intestinal epithelial cells are also present in $R I P 3^{-/}$mice (37). Findings of those studies suggest that there may be a delicate balance between different cell deaths in maintaining homeostasis in adults.

\section{Infectious diseases}

Viral infections. Findings have shown the crucial role of necroptosis in inflammation during viral infection (Table I). The viruses use the host's signaling pathways, such as anti-apoptotic proteins, to enhance infection, thereby increasing its ability to replicate in the host cell. It has been reported that viral encoding protein involving the RHIM domain interacts with RIP1 and RIP3 to inhibit virus-induced cell death (38). Viral inhibitor of RIP activation (vRIA) disrupts the combination of DAI and RIP3, thereby suppressing cytomegalovirus-mediated necroptosis (9). By contrast, human cytomegalovirus differs in protein, which does not disrupt RIP3 binding with DAI; it works via blocking signaling downstream of MLKL (39). Experimental studies in mice lacking RIP3 have shown impaired virus-induced necroptosis and increased susceptibility to viral infections such as vaccinia virus, influenza $\mathrm{A}$ virus, and HSV-1 $(5,25,38,40)$ (Fig. 5).

Bacterial infections. Necroptosis also plays an important role in the inflammation caused by bacterial infections. Enteropathogenic E. coli (EPEC) has been shown to synthesize and secrete large amounts of the immunogenic effector protein NleB1 and modify the arginine residues of the Fas-associated death domain (FADD) and RIP1 death domains to prevent apoptosis and necroptosis $(41,42)$. EPEC lacking NleB1 fails to colonize intestinal epithelial cells, indicating that bacterial necroptosis is a protective mechanism of the organism (41,42). Similarly, the absence of RIP3 sensitizes host cells to Yelsonella. Moreover, the simultaneous knockout of FADD or caspase- 8 could make cells more sensitive $(43,44)$. 


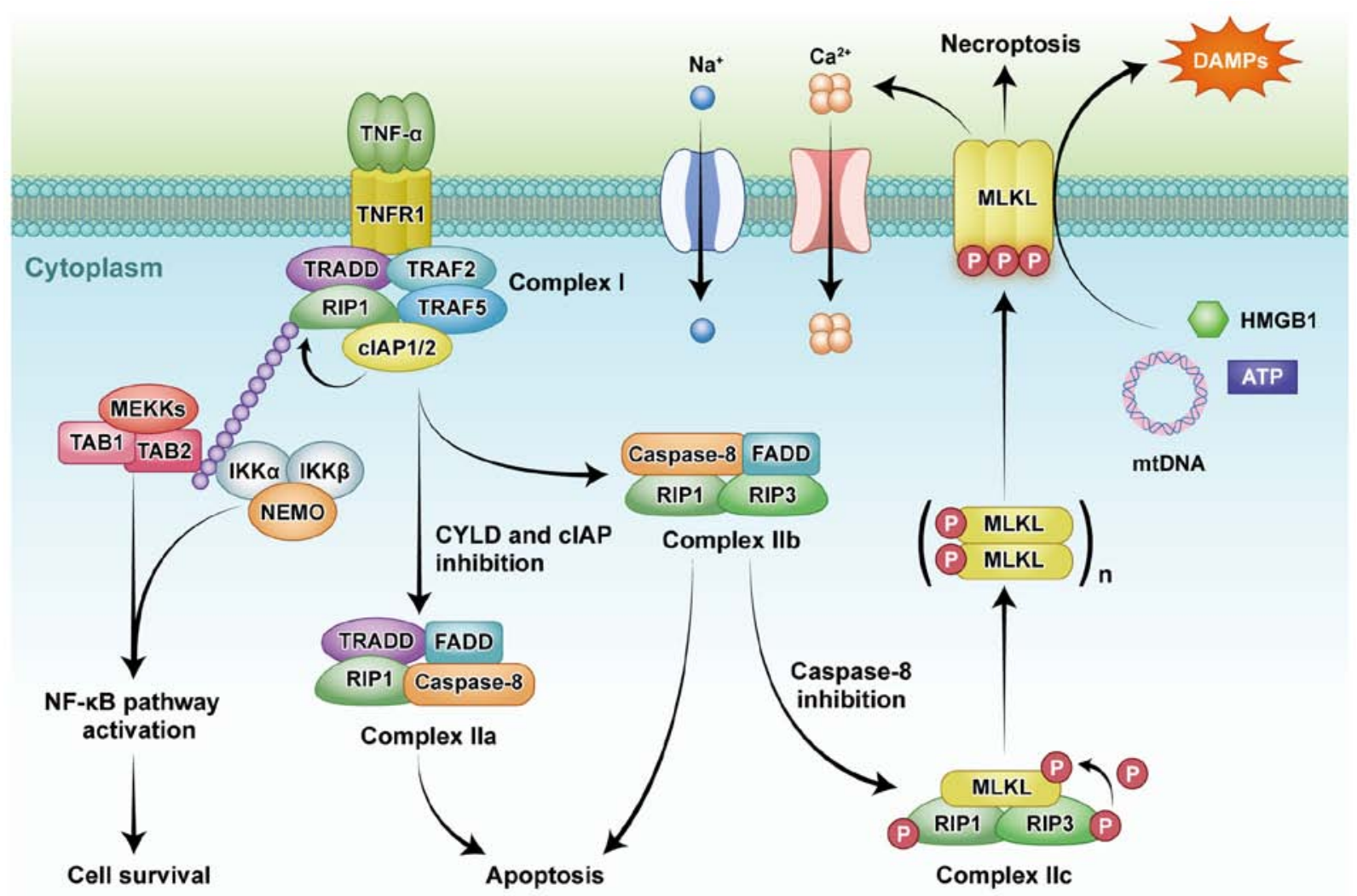

Figure 1. TNFR1-mediated survival and cell death pathways. After TNF binding, TNFR1 recruits TRADD and RIP1 to complex I via their respective death domains. TRADD recruits TRAF2 and cIAP1/2, after which cIAP1/2 ubiquitinate components of complex I. The ubiquitination of RIP1 promotes the formation and activation of the TAK1/TAB complex and the IKK $\alpha /$ IKK $\beta /$ NEMO complex, which induced the NF- $\mathrm{KB}$ pathway and cell survival. Deubiquitination of RIP1 by cylindromatosis (CYLD) induces the dissociation of TRADD and RIP1 from TNFR1, which leads to the formation of either complex IIa or complex IIb. FADD and pro-caspase-8 are recruited to TRADD and RIP1 to form complex IIa, resulting in the activation of caspase- 8 by oligomerization and cleavage. In the absence of cIAP1/2, TAK1 or IKK complex, complex IIb, which contains RIP1, FADD and pro-caspase-8 except TRADD, is formed and then activates caspase-8, after which caspase-8 induces apoptosis. When caspase- 8 activity is blocked, for example by zVAD-fmk, complex IIc/necrosome is formed, and RIP3-dependent necroptosis is induced. In the necrosome, RIP3 phosphorylates MLKL, and translocation of phosphorylated MLKL to the cell membrane leads to direct pore formation with the release of DAMPs. In spite of pore formation, MLKL also mediates its effect after interacting with ion channels.

1 RIP1 N

serine/threonine kinase domain

286

intermediate domain $\begin{array}{rr}\text { RHIM } \\ 531 & 547\end{array}$

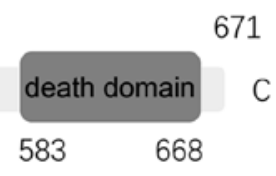

1

RIP3 N $\begin{array}{rrrrr}\text { serine/threonine kinase domain } & \text { intermediate domain } & \text { RHIM } & \text { C } \\ 22 & 280 & 424 & 469\end{array}$

Figure 2. Domain structure of RIP1 and RIP3. The intermediate domain of RIP1 contains the RIP homotypic interaction motif (RHIM) that enables the protein to combine with the RHIM in RIP3 to activate necroptosis. Length is indicated in a number of amino acids.

In vitro, Salmonella typhimurium is able to escape TNF $\alpha$, causing RIP1- and RIP3-dependent necroptosis in infected macrophages. In a model of Salmonella typhimurium venous infection, RIP3 knockout significantly reduces splenic macrophage death, thereby reducing bacterial numbers and prolonging mouse survival $(45,46)$. Findings focusing on oral Salmonella typhimurium infection have also shown that outer protein B was downregulated during infection, which resulted in promoting bacterial translocation, increasing macrophage necroptosis, and exacerbating bacterial infection (Table I) (47).
Parasite infections. Parasitic diseases such as malaria and leishmaniasis usually cause hemolysis, anemia, and bleeding. These are due to the release of hemoglobin $(\mathrm{Hb})$ into the circulation by the rupture of red blood cells. When $\mathrm{Hb}$ is oxidized, heme is generated, the Fenton reaction starts, and peaks with the generation of reactive oxygen species (ROS). Heme is also involved in the activation of TLR4, causing autocrine secretion of ROS and TNF, and synergistically activating RIP1/3-dependent necroptosis (48). In addition, it has been shown that $10 \mathrm{ng} / \mathrm{ml} \mathrm{TNF} \alpha$ can induce infected 


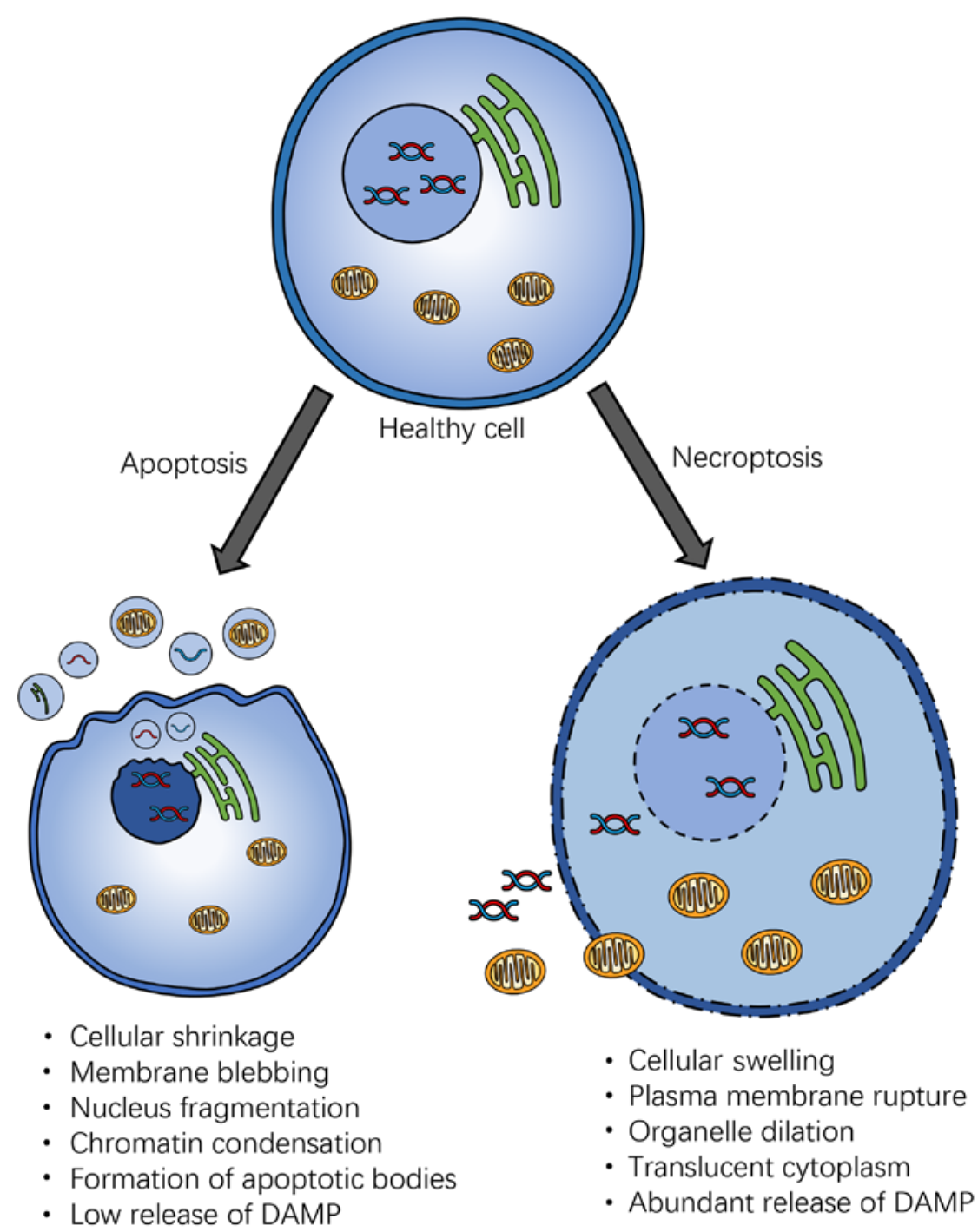

Figure 3. Difference of the key characteristics between apoptosis and necroptosis. Necroptosis is characterized by the swelling of organelles, gradually translucent cytoplasm, and rupture of the cellular membrane. The rupture of the cellular membrane results in the release of cellular contents, leading to the exposure of DAMPs, triggering a strong inflammatory response in necroptosis. Apoptosis is characterized by membrane blebbing, cell shrinkage, nuclear fragmentation, and chromatin concentration, with DAMPs restricted to the plasma membrane, or encapsulated in the apoptotic bodies.

human foreskin fibroblasts egressing Toxoplasma gondii (Table I) (49).

\section{Cancers}

Type of cancers. Studies on necroptosis highlight its role in cancer because of its necroptosis-inducing function (Table II) (50). Chen et al suggested that necroptosis is an important cell death mechanism for blocked apoptosis, and has been proposed as an alternative cell death procedure to prevent cancer (20). Previous studies have shown that a decreased expression of RIP3 or MLKL is associated with worse prognosis and poor survival in breast cancer $(51,52)$, colorectal cancer (53-55), acute myeloid leukemia $(56,57)$, melanoma $(58,59)$, head and neck squamous cell carcinoma (60), gastric cancer (61), ovarian cancer (62), and cervical squamous cell carcinoma (63). However, increased RIP3 or RIP1 expression was also correlated with cancer development, including glioblastoma (64), lung cancer (65), and pancreatic cancer $(66,67)$. SN38, the topoisomerase inhibitor, was found to be able to promote necroptosis progression, inhibit cell proliferation, and induce DNA damage accumulation in colon cancer (68). These findings indicate that inhibiting activities of necroptosis components may be a strategy in the treatment of cancers.

Metastasis. Metastasis is the most common cause of cancer-related death. Researchers have found that metastasis involves a complex interaction between cancer cells and the microenvironment. By promoting inflammation, necroptosis may be able to promote metastasis (69). It has been shown that $\mathrm{TNF} \alpha$ plays a critical role in cancer progression. However, the exact mechanism of this process has not been fully understood. Increased expression of $\mathrm{TNF} \alpha$ in cancer is a key characteristic in numerous malignancies and is usually associated with a poor prognosis and decreased survival (69). Consistent with the pro-inflammatory properties of necroptosis and the cancer-promoting effect of inflammation, Nec-1 was able to reduce inflammation and colitis-related tumor formation (70), indicating that targeting necroptosis may be a strategy for preventing cancer metastasis. 
Table I. The role of necroptosis in infectious diseases.

\begin{tabular}{|c|c|c|c|}
\hline Type of infections & & Observations & (Refs.) \\
\hline \multirow[t]{7}{*}{ Viral infections } & HSV-1 & $\begin{array}{l}\text { HSV-1-Induced necroptosis is partially dependent on RIP1, and fully } \\
\text { dependent on RIP3 and MLKL }\end{array}$ & $(38)$ \\
\hline & Influenza A virus & $\begin{array}{l}\text { Mice deficient in RIPK } 3 \text { is more susceptible to influenza A } \\
\text { virus than wild-type counterparts }\end{array}$ & (40) \\
\hline & MCMV & $\begin{array}{l}\mathrm{RIP}^{-/-} \text {murine embryonic fibroblasts were resistant to } \\
\text { MCMV-induced necrosis }\end{array}$ & $(9,156)$ \\
\hline & HIV-1 & $\begin{array}{l}\text { Necrostatin-1 restrains HIV-1-induced cytopathic effect and inhibits } \\
\text { the formation of HIV-induced syncytia in CD4+ T-cell lines }\end{array}$ & $(157)$ \\
\hline & Reovirus & $\begin{array}{l}\text { Cell death following reovirus infection was sensitive to } \\
\text { inhibition of RIP1 }\end{array}$ & $(158)$ \\
\hline & Vaccinia virus & $\begin{array}{l}R I P 1^{-/-} \text {mice cells infected with Vaccinia virus was resistant to } \\
\text { TNF- } \alpha \text { induced death }\end{array}$ & (159) \\
\hline & & $\begin{array}{l}R I P 3^{-/-} \text {mice exhibited severely impaired virus-induced tissue } \\
\text { necrosis and inflammation }\end{array}$ & $(5)$ \\
\hline \multirow[t]{6}{*}{ Bacterial infections } & $\begin{array}{l}\text { Clostridium prefringens } \\
\beta \text {-toxin }\end{array}$ & $\begin{array}{l}\text { RIP1 or RIP3 inhibitors reduced both bacteria-induced } \\
\text { apoptosis and necrosis }\end{array}$ & $(160)$ \\
\hline & $\begin{array}{l}\text { Salmonella } \\
\text { typhimurium }\end{array}$ & $\begin{array}{l}\text { Inhibition of the RIP1 or RIP3 prevented the bacteria-induced } \\
\text { death of wild-type macrophages }\end{array}$ & $(47)$ \\
\hline & & $\begin{array}{l}\text { Deletion of MLKL rescued severity of bacteria-induced tissue } \\
\text { inflammatory }\end{array}$ & (45) \\
\hline & M.tuberculosis & $\begin{array}{l}\text { RIP1 and RIP3 morpholino knockdown reduced susceptibility of } \\
\text { zebrafish to Mycobacterium marinum }\end{array}$ & $(161)$ \\
\hline & Yersinia pestis & $\begin{array}{l}\text { Deficiency of both RIP3 and caspase- } 8 \text { completely abrogated } \\
\text { Yersinia-induced cell death }\end{array}$ & (44) \\
\hline & Staphylococcus aureus & $R I P 3^{-/-}$mice exhibited significantly improved staphylococcal clearance & $(162)$ \\
\hline \multirow[t]{2}{*}{ Parasite infections } & Toxoplasma gondii & $\begin{array}{l}\text { Blocking necroptosis by necrostatin- } 1 \text { has little impact on } \\
\text { TNF- } \alpha \text {-induced egress of } T \text {. gondii }\end{array}$ & (49) \\
\hline & $\begin{array}{l}\text { Leishmaniasis and } \\
\text { Malaria }\end{array}$ & $\begin{array}{l}\text { Inhibition of the RIP1 or RIP3 protected macrophages from } \\
\text { heme-induced cell death }\end{array}$ & $(48)$ \\
\hline
\end{tabular}

HSV-1, herpes simplex virus type 1; RIP, receptor-interacting protein kinase; MLKL, mixed lineage kinase domain-like protein; MCMV, murine cytomegalovirus; TNF $\alpha$, tumor necrosis factor- $\alpha$; HIV-1, human immunodeficiency virus type-1.

\section{Neurodegenerative diseases}

Parkinson's disease. Researchers have shown that necroptosis was activated in Parkinson's disease (PD), and may be associated with mitochondrial defects which led to necroptosis (Table III) (71). Compared with healthy brain, the level of necroptosis components, including RIP1, RIP3 and MLKL, was significantly increased in the substantia nigra of PD brain (72). Moreover, researchers have found Nec-1 could protect PC12 cells from death in PD models (73). This suggests that the activation of RIP1 may be a risk factor for dopaminergic neurons lost in PD patients. In addition, leucine-rich repeat kinase 2, which was identified in a systematic RNAi screen, is encoded by a gene that is frequently mutated in PD and is able to promote activation of RIP1 (74).

Alzheimer's disease. Alzheimer's disease (AD) is a degenerative brain disease featured by loss of neurons. Previous studies have found that there were activated necroptosis in both human (75) and mouse (76) AD brain. In the AD brain, the levels of necroptosis components, such as RIP1 and MLKL, were significantly higher than the normal brain (Table III) (75). Treatment of AD in brain of mice with the necroptosis inhibitor can significantly suppress necroptosis and prevent neuronal loss (75). This indicates that targeting necroptosis may be a new therapeutic strategy for $\mathrm{AD}$ treatment.

Amyotrophic lateral sclerosis. Amyotrophic lateral sclerosis (ALS) is a neurodegenerative disease that is characterized by loss of motor neurons. In a previous study, the ALS spinal cord was shown to have a significant increase in necroptosis components including RIP1, RIP3, and MLKL in the ALS mouse model compared to healthy mouse spinal cord (77). In addition, loss of optineurin, an ALS-related gene, resulted in susceptibility to necroptosis. Nec-1 inhibition of RIP1 or knockout of RIP3 could prevent demyelination and reduce axonal pathological hallmarks in ALS mouse models (Table III) (77). Those findings suggested that targeting necroptosis may have potential therapeutic value in ALS patients. 


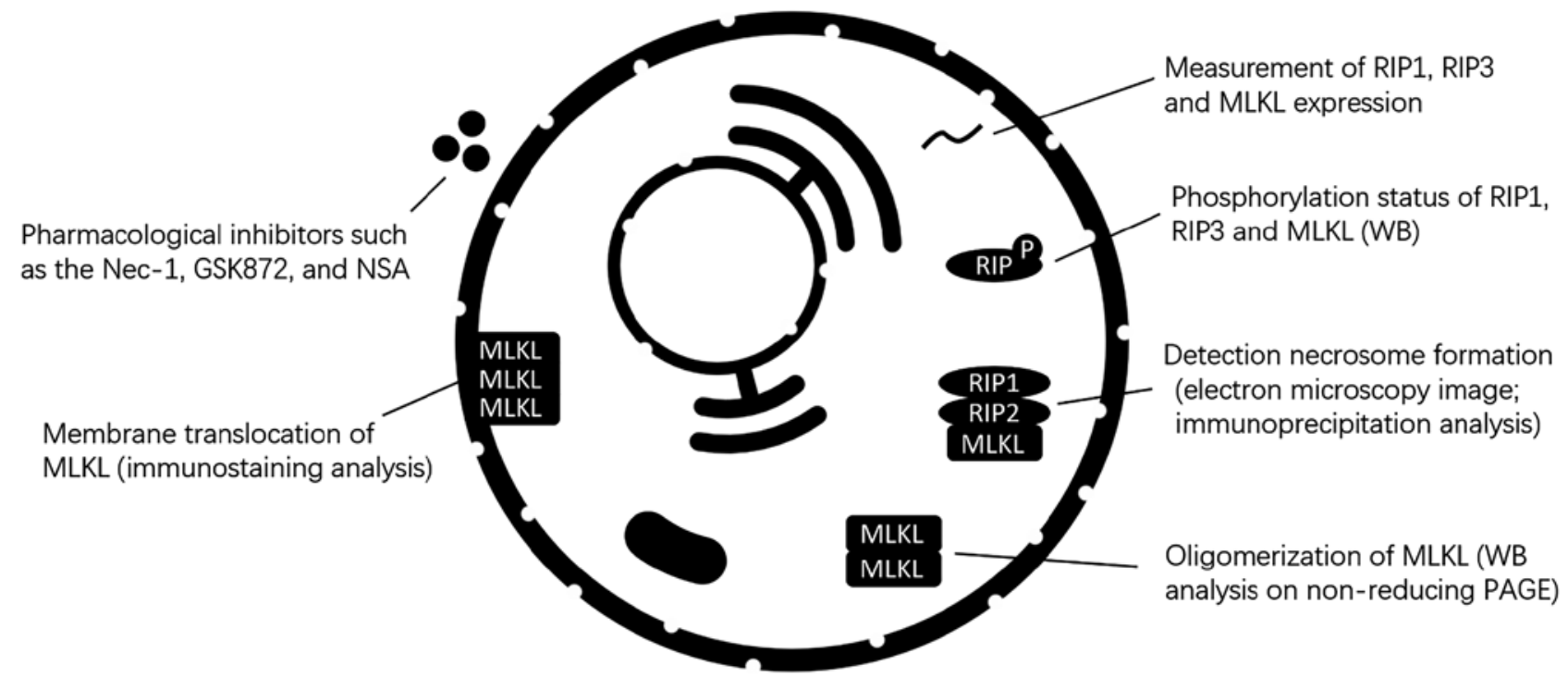

Figure 4. Methods to identify necroptosis. In cultured cells, transmission electron microscopy can be used to identify necroptotic cells. Detection of key molecular, including RIP1, RIP3 and MLKL activation, necrosome formation, MLKL oligomerization, and membrane translocation can also be used to identify necroptosis. Activation of RIP3 and MLKL can be monitored by western blot (WB) analysis to assess phosphorylation status. Several pharmacological inhibitors such as the Nec-1, GSK872, and NSA have also been used to detect necroptosis. In vivo, the activation of necroptosis can be identified by the elevated levels of RIP1, RIP3, or MLKL mRNA or protein.

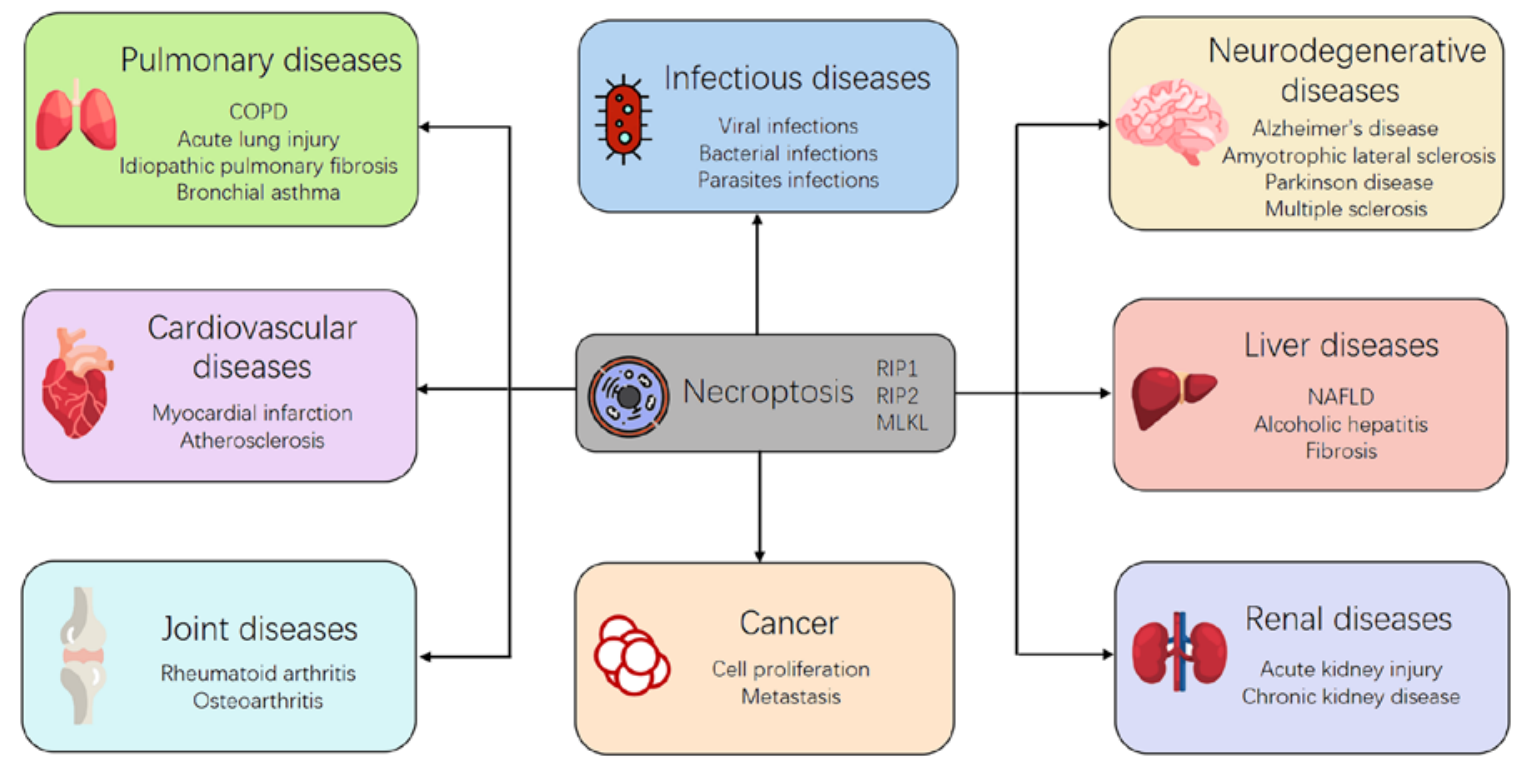

Figure 5. The potential role of necroptosis in clinical diseases. Necroptosis has been implicated in pathophysiological processes of several clinical diseases, including infectious diseases, neurodegenerative diseases, liver diseases, pulmonary diseases, renal diseases, cardiovascular diseases, joint diseases, and human tumors.

Multiple sclerosis. Multiple sclerosis (MS) is degenerative disease characterized by oligodendrocyte loss and demyelination. Previous findings have shown a significant increase in necroptosis components including RIP1, RIP3, and MLKL in MS patients. In addition, MLKL oligomers were significantly increased in MS pathology samples compared with controls (Table III) (78). This suggests necroptosis is activated in the pathogenesis of MS. In MS mouse model, oral administration of RIP1 inhibitor can suppress oligodendrocyte degeneration and reduce disease severity (78). Moreover, researchers have shown that inhibition of RIP1 reduced demyelination and disease progression in an MS model (79). Notably, MLKL was shown to be involved in the MS process (79).

Liver diseases. Non-alcoholic fatty liver disease (NAFLD), Non-alcoholic fatty liver disease (NAFLD) is a chronic disease characterized by excess triglyceride accumulation in the liver. Several studies have used different models to assess the effects of necroptosis on NAFLD (Table IV). Studies have found necroptosis components, including RIP1, RIP3 and MLKL, were increased in NAFLD models, as well as in RIP3KO mice (80-85). In addition, an increased expression of RIP3 and MLKL in the human NAFLD was 
Table II. The role of necroptosis in cancer.

\begin{tabular}{|c|c|c|}
\hline Cancer type & Observations & (Refs.) \\
\hline Breast cancer & Decrease of RIP3 expression was associated with worse prognosis & $(51,52)$ \\
\hline Colorectal cancer & Decrease RIP3 and MLKL expression were associated with decreased overall survival & $(53-55)$ \\
\hline Gastric cancer & Low MLKL expression was significantly associated with decreased overall survival & $(61)$ \\
\hline Ovarian cancer & Decrease of MLKL expression was associated with worse prognosis & $(62)$ \\
\hline Pancreatic cancer & $\begin{array}{l}\text { Increase of RIP1, RIP3, FADD and MLKL expression were associated with worse } \\
\text { prognosis }\end{array}$ & $(66,67)$ \\
\hline Lung cancer & Increased RIP1 expression was associated with worse prognosis & $(65)$ \\
\hline Acute myeloid leukemia & Decrease of RIP3 expression was associated with worse prognosis & $(56,57)$ \\
\hline Melanoma & Decrease of RIP3 expression was associated with worse prognosis & $(58,59)$ \\
\hline $\begin{array}{l}\text { Head and neck squamous } \\
\text { cell carcinoma }\end{array}$ & Decrease of RIP1 expression was associated with worse prognosis & $(60)$ \\
\hline $\begin{array}{l}\text { Cervical squamous cell } \\
\text { carcinoma }\end{array}$ & Decrease of MLKL expression was associated with worse prognosis & $(63)$ \\
\hline Glioblastoma & Increased RIP1 expression was associated with worse prognosis & $(64)$ \\
\hline
\end{tabular}

RIP, receptor-interacting protein kinase; MLKL, mixed lineage kinase domain-like protein; FADD, Fas-associated death domain.

Table III. The role of necroptosis in neurodegenerative diseases.

\begin{tabular}{lll}
\hline Neurodegenerative diseases & \multicolumn{1}{c}{ Observations } \\
\hline Parkinson's disease & $\begin{array}{l}\text { RIP1 inhibition improved survival of optic atrophy 1-mutant human induced pluripotent } \\
\text { stem cell-derived neurons in vitro. RIP1 inhibition attenuated MPTP-induced } \\
\text { dopaminergic neuronal loss } \\
\text { RIP1 inhibition reduced A } \beta \text { burden, levels of inflammatory cytokines, and memory } \\
\text { deficits in a mouse model of Alzheimer's disease } \\
\text { Alzheimer's disease }\end{array}$ & $\begin{array}{l}\text { RIP1 inhibition or RIP3 deficiency blocked oligodendrocyte death, microglial } \\
\text { inflammation, and axonal degeneration }\end{array}$ \\
Amyotrophic lateral & Cortical lesions in human multiple sclerosis brain samples showed increased activation of \\
sclerosis & RIP1, RIP3 and MLKL \\
Multiple sclerosis & Inhibition of RIP1 inhibited the progression of demyelination and disease development \\
& in a cuprizone-induced model for multiple sclerosis
\end{tabular}

RIP, receptor-interacting protein kinase; MPTP, 1-methyl-4-phenyl-1,2,3,6-tetrahydropyridine; MLKL, mixed lineage kinase domain-like protein.

identified $(83,85)$. Increased level of RIP3 and p-MLKL was also found in visceral adipose tissue of obese patients. Furthermore, RIP3 expression correlated with p-MLKL and metabolic serum markers including blood insulin levels and Hemoglobin A1c (84).

Alcoholic hepatitis. Similar to the pathologies of NAFLD, alcoholic hepatitis is an inflammatory syndrome in liver, which can result in high morbidity and mortality. Several studies have found that RIP3 was increased following ethanol feeding, and RIP3 deletion could protect the liver from ethanol-mediated injury (Table IV). In addition, p-JNK was regulated by RIP3 in a model of alcoholic hepatitis, and RIP3 deletion reduced ethanol-induced p-JNK expression (86). Another study found pharmacological inhibition of proteasome and liver-specific
PSMC1 KO mice could increase RIP3 expression, indicating RIP3 expression was post-translationally regulated in ethanol-mediated liver injury (87). Additionally, when RIP3 was deleted, the steatosis and inflammatory effects of ethanol in hepatocyte could be reduced (86). However, the inflammatory and steatosis effects of high fat diet for hepatocyte were increased when RIP3 was deleted (80).

Fibrosis. Hepatic fibrosis is one of the most common liver diseases, which is closely related to liver failure and hepatocellular cancer. RIP3 deletion reportedly aggravated hepatic fibrosis by increasing insulin resistance (80). Furthermore, inhibition of RIP3 did not result in protective effect in carbon tetrachloride (CCL4)-induced fibrosis (83) (Table IV). Additionally, curcumol suppressed serum inflammatory 
Table IV. The role of necroptosis in liver diseases.

\begin{tabular}{ll} 
Liver diseases & \multicolumn{1}{c}{ Observations } \\
\hline NAFLD & MLKL deficiency and necrostatin-1 administration improves insulin sensitivity without affecting \\
& inflammation \\
& RIP3KO mice had increased hepatic steatosis but reduced inflammation \\
& MCD diet-fed RIP3KO mice were protected, but CCL4-induced fibrosis model mice were not \\
& protected \\
& RIP3 maintains WAT homeostasis and has a role in WAT insulin signaling \\
& RIP3 deficiency protects from steatosis, inflammation, and fibrosis \\
Alcoholic hepatitis & RIP3 expression increased following ethanol feeding \\
& RIP3 but not RIP1 inhibition protects from ethanol-induced hepatic injury and steatosis \\
& RIP3 ablation and necrostatin-1 decreased hepatic inflammation \\
& Curcumin reduced ethanol-induced necroptosis in Nrf/p53-dependent mechanism \\
& RIP3KO mice were not protected against steatosis, inflammation and fibrosis \\
& RIP3 deficiency protects from steatosis, inflammation, and fibrosis \\
& RIP3KO MCD diet-fed mice were protected from inflammation and fibrosis, while CCL4-induced \\
& fibrosis was not reduced in RIP3KO mice \\
Fibrosis & RIP3 deficiency reduced inflammation, oxidative stress, and fibrosis in 3-day CBD ligation model \\
& Melatonin protects from CCL4-induced fibrosis \\
Curcumol-mediated decreased fibrosis is associated with increased necroptosis in hepatic \\
stellate cells
\end{tabular}

NAFLD, non-alcoholic fatty liver disease; RIP, receptor-interacting protein kinase; KO, knockout; MCD, methionine and choline-deficient; CCL4, carbon tetrachloride; WAT, white adipose tissue; CBD, common bile duct.

markers, transaminases, and fibrosis in a dose-dependent manner by inducing necroptosis of hepatic stellate cells in a liver fibrosis model (88). Curcumol-induced increased necroptosis was mediated by increased expression of p-RIP3 and p-JNK (88). Those results indicated that pharmacotherapy which induced increased necroptosis may be a notable strategy for the treatment of hepatic fibrosis in the future.

\section{Pulmonary diseases}

Chronic obstructive pulmonary disease. Chronic obstructive pulmonary disease (COPD) is characterized by persistent and progressive airway inflammation and narrowing, and is a major source of the high healthcare expenditure in the elderly (89). An increasing number of studies have shown that necroptosis is associated with the etiology of COPD (Table V). In addition, necroptosis of epithelial cell is associated with COPD (90). Cigarette smoking (CS)-related necroptosis and DAMP release could cause neutrophil inflammation in mice, and Nec-1 could reduce the inflammation (91). In addition, researchers have found that in airway epithelial cells, endoplasmic reticulum chaperone protein GRP78 could promote CS-induced inflammation. This may be due to the upregulation of necroptosis and subsequent activation of the NF- $\mathrm{KB}$ pathway (92).

Acute lung injury. Acute lung injury (ALI) is one of the most common complications in critically ill patients (93). Recent findings have shown the involvement of RIP3-mediated necroptosis in neonatal mice with hypoxia-induced lung injury, which can be attenuated by gene deletions in RIP3 (94). In additional, inhibition of RIP3 could significantly reduce inflammatory activation and lipopolysaccharide-induced necroptosis (95). Researchers have also found that mice lacking RIP3 were protected from ventilator-induced lung injury (96). Additionally, inhibition of RIP1 can reduce systemic and pulmonary inflammation and increase survival rate of septic neonatal mice (Table V) (97).

Idiopathic pulmonary fibrosis. Idiopathic pulmonary fibrosis (IPF) is a chronic, progressive, fibrotic lung disease characterized by the usual interstitial pneumonia pattern at histopathologic examination (98). In a previous study using alveolar epithelial cells, RIP3-mediated necroptosis was associated with IPF development by releasing DAMP (99). Additionally, RIP3 and p-MLKL levels in the lungs of IPF patients are significantly higher than those in healthy lungs (99). Mice with RIP3 knockout showed a reduced cell death, with a decrease of p-MLKL level in alveolar epithelial cells (99). RIP3 knockout could effectively suppress the DAMP releasing, cell death, and pulmonary fibrosis without reducing the expression of cleaved caspase-3 (Table V) (99). These indicate that inhibiting activities of necroptosis components may be a strategy in the treatment of IPF.

Bronchial asthma. Bronchial asthma is the most common chronic respiratory disease characterized by bronchial hyper-responsiveness and airway obstruction (100). Viral-induced bronchial asthma exacerbation mimicked by IFN- $\beta$ knockout mice treated with house dust mite is associated with increased necroptosis components, including p-MLKL and LDH in the bronchoalveolar lavage fluid (101). As a major inflammatory cytokine in bronchial asthma, IL-33 
Table V. The role of necroptosis in pulmonary diseases.

Pulmonary diseases

Observations

(Refs.)

COPD

Acute lung injury

Idiopathic

pulmonary fibrosis

Bronchial asthma
CS-induced necroptosis and the release of DAMPs trigger neutrophilic inflammation in mice that was reduced with Nec-1 treatment

RIP3-mediated necroptosis is observed in neonatal mice with HALI, which is attenuated by genetic deletion in RIP3

RIP3-deficient mice are protected against ventilator-induced lung injury

RIP3 and p-MLKL expression levels are significantly higher in the lungs of IPF patients than in

healthy control lungs

Bleomycin-treated AECs isolated from RIP3 knockout mice show attenuation of cell death with decreased p-MLKL expression

GW806742X can abrogates IL-33 reaction in vitro and attenuates eosinophilia in a mouse model of asthma

COPD, chronic obstructive pulmonary disease; CS, cigarette smoking; DAMPs, damage-associated molecular patterns; RIP, receptor-interacting protein kinase; MLKL, mixed lineage kinase domain-like protein; HALI, hypoxia-induced lung injury; IPF, idiopathic pulmonary fibrosis; AECs, alveolar epithelial cells; IL-33, interleukin 33.

Table VI. The role of necroptosis in renal diseases.

Renal diseases

Observations

(Refs.)

Acute kidney injury

$\mathrm{RIP}^{-/-}$and $\mathrm{MLKL}^{-/-}$mice are less sensitive to oxalate crystal-induced and cisplatin-driven

AKI than are their wild-type counterparts

The RIP3 $^{--}$genotype confers considerable protection against mild IRI, and such a

protection can be extended to severe IRI by the concomitant deletion of Ppif

Chronic kidney disease RIP1 and RIP3 participate in the loss of renal cells of subtotal nephrectomised rats

Gene deletion of RIP3 or MLKL ameliorated renal tubular cell necroptosis, and then finally

reduced interstitial fibrogenesis in the long term after IRI

RIP, receptor-interacting protein kinase; MLKL, mixed lineage kinase domain-like protein; AKI, acute kidney injury; IRI, ischemia-reperfusion injury.

is released in response to necroptosis and causes eosinophil and basophil activation (102). Moreover, in a mouse model of asthma induced by Aspergillus fumigatus extract, the necroptosis inhibitor GW806742X can eliminate necroptosis and IL-33 response, and attenuates eosinophilia (102). Additionally, The TNF $\alpha$-induced necroptosis enhanced by mucin 1 can be reduced by Nec-1 in human bronchial epithelial cells (103) (Table V).

\section{Renal diseases}

Acute kidney injury. Acute kidney injury (AKI) is a common and severe clinical disease that often requires renal replacement therapy (Table VI). Signs of an ongoing necroptotic response have been found in AKI caused by ischemia-reperfusion injury (IRI) (104-106), urolithiasis (107), cisplatin-based chemotherapy or radiocontrast $(104,108-111)$. Previous findings have shown that compared with wild-type counterparts, $R I P 3^{-/}$and $M L K L^{-/-}$mice are less sensitive to oxalate crystal-induced AKI, and are associated with reduced plasma creatinine levels, neutrophil infiltration, and limited tubular injury $(107,110)$. Moreover, the $R I P 3^{-/-}$mice confer protection from mild IRI, and the protection can be extended to severe IRIs with the deletion of Ppif (104). Similar results are also found when Nec-1, SfA, and 16-86 are employed alone or in combination $(104,109)$. The abovementioned results suggest that inhibition of necroptosis may be a therapeutic option for AKI treatment.

Chronic kidney disease. Similar to the AKI, necroptosis was also found in chronic kidney disease (CKD) after unilateral nephrectomy (Table VI) (112). Researchers have shown that necroptosis and the highest levels of RIP1 and RIP3 occurred 8 weeks after subtotal nephrectomy (112). Notably, the renal pathological changes and renal function could be significantly improved after Nec-1 treatment, and the overexpression of RIP1, RIP3, MLKL could be significantly reduced (112). These results suggest that necroptosis contributes to the loss of renal cells in subtotal nephrectomized rats. Furthermore, during the AKI to CKD process, upregulation of expression and interaction between RIP3 and MLKL can induce necroptosis in proximal renal tubular cells and promote inflammasome activation under IRI conditions (113). RIP3 or MLKL knockout could protect the renal tubular cells from necroptosis and 
Table VII. The role of necroptosis in cardiovascular diseases.

\begin{tabular}{ll}
\hline Cardiovascular diseases & \multicolumn{1}{c}{ Observations } \\
\hline Myocardial infarction & $\begin{array}{l}\text { RIP3 deficiency protects mouse hearts from IR-induced necroptosis and significantly } \\
\text { reduces infarct size } \\
\text { Necrostatin-1 prevents both short and long-term effects of myocardial ischemia } \\
\text { Ox-LDL deposited in the endothelium can upregulate the expression of RIP3 and } \\
\text { Otherosclerosis }\end{array}$ \\
\hline
\end{tabular}

(Refs.)

RIP, receptor-interacting protein kinase; IR, ischemia-reperfusion; ox-LDL, oxidized-low-density lipoprotein.

Table VIII. The role of necroptosis in joint diseases.

\begin{tabular}{ll}
\hline Joint diseases & \multicolumn{1}{c}{ Observations } \\
\hline Rheumatoid arthritis & $\begin{array}{l}\text { RIP1, RIP3 and MLKL were potently increased in the synovium of a collagen-induced RA } \\
\text { mouse model } \\
\text { RIP1 inhibitor significantly decreased the expression of RIP1, RIP3 and MLKL and } \\
\text { suppressed the expression of IL-17, IL-1 } \beta, \text { IL-6 and TNF } \alpha \text { in a RA mouse model }\end{array}$ \\
Osteoarthritis & $\begin{array}{l}\text { Gene expression levels of RIP3 and MLKL were elevated in highly degenerated cartilage tissue } \\
\text { Trauma induced cell death and subsequent release of pro-inflammatory mediators could be } \\
\text { largely attenuated by necrostatin-1 or N-acetylcysteine }\end{array}$
\end{tabular}

(Refs.)

RA, rheumatoid arthritis; RIP, receptor-interacting protein kinase; MLKL, mixed lineage kinase domain-like protein; IL, interleukin; TNFa: tumor necrosis factor- $\alpha$.

inflammasome activation, which prevent kidney from interstitial fibrogenesis after IRI (113).

\section{Cardiovascular diseases}

Myocardial infarction. Myocardial infarction, characterized by regional myocardial ischemia and hypoxia, is one of the leading causes of death worldwide (114). Previous findings have shown that compared to wild-type mice, the levels of RIP1 and RIP3 were significantly higher in hearts of ischemic mice $(22,115)$. In an acute IRI mouse model, RIP3 deficiency was able to protect heart from IRI-induced necroptosis and reduce the infarct size (116). Notably, researchers have found that Nec-1 could protect heart against short-term and long-term effects of myocardial ischemia, including reduced necrotic cell death and size of myocardial infarction, which helped to maintain long-term cardiac function (22) (Table VII).

Atherosclerosis, Atherosclerosis, a chronic inflammatory disease, is frequently observed in middle-aged individuals and the elderly, and is a major cause of cardiovascular death (117). It has been demonstrated that necroptosis may promote the inflammatory response and atherosclerosis development. Oxidized low-density lipoprotein (LDL) is able to upregulate RIP3 and oxidized LDL-related gene expression in macrophages, leading to macrophage necroptosis (118). It triggers an inflammatory response, which leads to atherosclerosis. During the progression of the disease, some cytokines are released and monocytes accumulate in the lesion, exacerbating the accumulation of inflammation. Additionally, necroptosis can lead to the death of foam cells, which in turn aggravates the progression of the disease (Table VII) (118). These results suggest that inhibition of necroptosis may be a therapeutic option for atherosclerosis treatment.

\section{Joint diseases}

Rheumatoid arthritis. Rheumatoid arthritis (RA), characterized by synovial membrane inflammation, is a chronic systemic inflammatory autoimmune disease that affects $0.5-1 \%$ of the population worldwide (119). Previous findings have shown a significant increase in necroptosis components including RIP1, RIP3, and MLKL in the synovium of an arthritis mouse model (120). Additionally, researchers have also found in an arthritis mouse model, Nec-1 could significantly reduce these key components of necroptosis and IL-17, IL-1 $\beta$, IL-6, and TNF $\alpha$ (Table VIII) (121). These results suggested that inhibiting activities of necroptosis components may be a strategy in the treatment of RA.

Osteoarthritis. Osteoarthritis (OA) is the leading cause of pain and disability among chronic disease, which affects about $10 \%$ of men and $18 \%$ of women older than 60 years (122). A significant increase in necroptosis components including RIP3, and MLKL was found in highly degenerated cartilage tissue (123). Moreover, it has been shown that Nec-1 could significantly reduce cell death and subsequent release proinflammatory mediators in the OA model (Table VIII) (123).

\section{Drugs and agents that regulate necroptosis}

As necroptosis not only participate in the maintenance of organismal homeostasis, but also constitute etiological determinants of diverse human pathologies (124), at least two 
Table IX. Drugs and agents that regulate necroptosis.

\begin{tabular}{lll}
\hline Drugs and agents & \multicolumn{1}{c}{ Target } & Disease condition \\
\hline Drugs and agents that induce necroptosis & \\
\hline Interferons & RIP3 and MLKL & Different diseases \\
Valproic acid & RIP1 & Epilepsy and mood disorders \\
Decitabine and 5-azacytidine & RIP3 & Breast cancer \\
Shikonin & RIP1 and RIP3 & Pancreatic and non-small cell lung cancers, osteosarcoma \\
Emodin & RIP1, RIP3 and MLKL & Renal cancer \\
Bufalin & RIP1 and RIP3 & Pancreatic and breast cancers \\
Resibufogenin & RIP3 and MLKL & Pancreatic and colorectal cancers \\
Radiotherapy & Caspase-8 & Different cancers \\
5-fluorouracil & RIP1 and RIP3 & Different cancers \\
Cisplatin & RIP1, RIP3 and MLKL & Different cancers \\
Anthracyclines and oxaliplatin & RIP3 and MLKL & Lung cancer \\
Obatoclax & RIP1, RIP3 and MLKL & Different cancers \\
Neoalbaconol & RIP1 and RIP3 & Nasopharyngeal carcinoma \\
Tanshinone & RIP1 and RIP3 & Hepatocellular carcinoma \\
\hline
\end{tabular}

Drugs and agents that inhibit necroptosis

\begin{tabular}{|c|c|c|c|}
\hline Cyclosporine A & RIP1 and RIP3 & Immunosuppressive drug & $(133)$ \\
\hline Rapamycin & RIP1 & $\begin{array}{l}\text { Restenosis in coronary arteries, transplant rejection in } \\
\text { lymphangioleiomyomatosis, and retinal detachment }\end{array}$ & $(134)$ \\
\hline Patchouli alcohol & RIP3 and MLKL & Colitis & $(139)$ \\
\hline Pazopanib & RIP1 & Renal cell carcinoma and advanced soft tissue sarcoma & $(140)$ \\
\hline Ponatinib & RIP1 and RIP3 & Leukemia & $(140)$ \\
\hline GSK2982772 & RIP1 & Inflammatory diseases (colitis, rheumatoid arthritis, psoriasis) & $(167)$ \\
\hline GSK3145095 & RIP1 & Pancreatic cancer & $(141)$ \\
\hline Dabrafenib & RIP3 & Melanoma & $(88)$ \\
\hline Carfilzomib & RIP3 and MLKL & Multiple myeloma & $(142)$ \\
\hline Sorafenib & RIP1 and RIP3 & Thyroid and renal cell cancers, hepatocellular carcinoma & $(143)$ \\
\hline Phenytoin & RIP1 & Epilepsy and breast cancer & $(144)$ \\
\hline Aucubin & RIP1 and MLKL & Epilepsy & $(145)$ \\
\hline Wogonin & RIP1 & Acute kidney injury & $(146)$ \\
\hline
\end{tabular}

therapeutic paradigms can be envisioned: i) the activation of necroptosis, as a means to bypass the accrued resistance of most tumors to apoptosis (125); ii) the inhibition of necroptosis, as a strategy to limit the loss of post-mitotic cells in pathologies such as inflammatory, ischemic, and toxic syndromes (126). Therefore, drugs affecting either the expression or the activity of necroptosis mediators may have therapeutic potential (Table IX).

Several drugs have been found to upregulate the expression of the key molecules of necroptosis, including interferons (127), histone deacetylase inhibitor valproic acid (128), and hypomethylating agents such as decitabine and 5-azacytidine (51). Additionally, several traditional Chinese medicine drugs such as shikonin (129), emodin (130), bufalin (131), and resibufogenin (132) were also found to upregulate RIP1 and RIP3, which finally induced necroptosis. By contrast, various drugs have been documented to downregulate necroptosis, including immunosuppressive drug Cyclosporine A (133) and
Rapamycin (134), inhibitors of the HSP90 [(G-TPP) (135), Kongensin A (136), 17-demethoxy-reblastatin (137), DHQ3 (137), gamitrinib (18), and geldanamycin (138)], as well as traditional Chinese medicine such as patchouli alcohol (139).

Promising specific inhibitors are also being developed for the central molecules of necroptosis. Currently, several drugs with anti-necroptotic activity have been used for the treatment of different types of cancer [Pazopanib (140), Ponatinib (140), GSK3145095 (141), Dabrafenib (26), Carfilzomib (142), and Sorafenib (143)]. Moreover, a clinically used anti-convulsant, Phenytoin (144) as well as components found in different plants [aucubin (145) and wogonin (146)] could inhibit RIPK1 activity. By contrast, radiotherapy (147), chemotherapeutic agents such as 5-fluorouracil (148), cisplatin (149), oxaliplatin (150), and anthracyclines (150), pan-BCL-2 inhibitor Obatoclax (151), or traditional Chinese medicines such as neoalbaconol (152) and tanshinone (153) have been documented to upregulate 
necroptosis. Although these drugs did not affect the expression of necroptotic component, these medicines may increase the effect of the drugs affecting the expression of the necroptotic molecules in combination therapy in cancer cells.

\section{Conclusions and perspectives}

During the last decade, necroptosis has been recognized as an alternative to apoptosis when cells are exposed to various stimuli under specific conditions (154). The necrosome components, RIP1, RIP3, and MLKL, are critical regulators of necroptotic cell death. RIP1 functions as a traffic cop for mechanisms of cell death. MLKL acts as the executioner of necroptosis, based on the phosphorylation, oligomerization and membrane translocation (155). Current understandings demonstrated a pathway in which RIP3 activation, possibly mediated by RIP1, induces MLKL activation, and finally results in permeabilization of the plasma membrane and cell death.

Recent studies have revealed a complex role for necroptosis in diverse clinical diseases, such as ischemia-reperfusion injury, neurological and inflammatory diseases, retinal disorders, acute kidney injury or bacterial infections. On the one hand, it functioned as a cell-death mechanism activated by various signal transduction cascades in the same cell or the same tissue; on the other hand, it acted as an inflammation inducer through the release of DAMPs. Cross-regulation between necroptosis and other modes of cell death increase the complexity of these pathways. The major necroptosis-regulating proteins exert pleiotropic signaling functions that culminate in necroptotic cell death and have cell death-independent functions, such as regulation of inflammasome activation, mitochondrial function and integrity, and cellular metabolic activities (96).

As necroptosis constitutes etiological determinants of multiple human pathologies, targeting the necroptotic pathway is a potential therapeutic approach for multiple diseases, and several activators or inhibitors of the necroptosis pathway have been developed, such as dabrafenib, pazopanib, and ponatinib. These small-molecule activators or inhibitors of necroptosis may be useful as therapeutics in a specific clinical disease. However, most studies investigating the therapeutics targeting necroptosis are based on in vitro experiments or animal models, thus the feasibility of the clinical use of these compounds and agents remains to be assessed in vivo and clinical trials. Additionally, the off-target effects of the necroptosis-targeting therapeutics should be scrutinized, and novel approaches that conjugate necroptosis inducers and disease-guiding agents should be developed to enhance selectivity and safety.

\section{Acknowledgements}

The authors are grateful to Dr He Xiao for his valuable advice and English editing.

\section{Funding}

This work was supported by grants from the National Natural Science Foundation of China (nos. 81672212, 81802153 and 81902205), the Beijing Natural Science Foundation (nos. 7171014, 7174361 and 7182175), and the Beijing Municipal Science and Technology Commission (no. Z171100001017085).

\section{Availability of data and materials}

Not applicable.

\section{Authors' contributions}

YFA and WLD conceived the study; JC and XQH were involved in data curation; XL, WLD and JC were involved in collection of references as well as writing and editing; YFA, $\mathrm{XQH}$ and JC supervised the study. All authors have read and agreed to the published version of the manuscript.

\section{Ethics approval and consent to participate}

Not applicable.

\section{Patient consent for publication}

Not applicable.

\section{Competing interests}

The authors declare that they have no competing interests.

\section{References}

1. Galluzzi L, Vitale I, Abrams JM, Alnemri ES, Baehrecke EH, Blagosklonny MV, Dawson TM, Dawson VL, El-Deiry WS, Fulda S, et al: Molecular definitions of cell death subroutines: Recommendations of the Nomenclature Committee on Cell Death 2012. Cell Death Differ 19: 107-120, 2012.

2. Moriwaki K, Balaji S, McQuade T, Malhotra N, Kang J and Chan FK: The necroptosis adaptor RIPK3 promotes injury-induced cytokine expression and tissue repair. Immunity 41: 567-578, 2014.

3. Holler N, Zaru R, Micheau O, Thome M, Attinger A, Valitutti S, Bodmer JL, Schneider P, Seed B and Tschopp J: Fas triggers an alternative, caspase-8-independent cell death pathway using the kinase RIP as effector molecule. Nat Immunol 1: 489-495, 2000.

4. He S, Wang L, Miao L, Du F, Zhao L and Wang X: Receptor interacting protein kinase-3 determines cellular necrotic response to TNF-alpha. Cell 137: 1100-1111, 2009.

5. Cho YS, Challa S, Moquin D, Genga R, Ray TD, Guildford M and Chan FK: Phosphorylation-driven assembly of the RIP1-RIP3 complex regulates programmed necrosis and virus-induced inflammation. Cell 137: 1112-1123, 2009.

6. Zhang DW, Shao J, Lin J, Zhang N, Lu BJ, Lin SC, Dong MQ and Han J: RIP3, an energy metabolism regulator that switches TNF-induced cell death from apoptosis to necrosis. Science 325: 332-336, 2009

7. Sun L, Wang H, Wang Z, He S, Chen S, Liao D, Wang L, Yan J, Liu W, Lei X and Wang X: Mixed lineage kinase domain-like protein mediates necrosis signaling downstream of RIP3 kinase. Cell 148: 213-227, 2012.

8. Jouan-Lanhouet S, Riquet F, Duprez L, Vanden Berghe T, Takahashi $\mathrm{N}$ and Vandenabeele $\mathrm{P}$ : Necroptosis, in vivo detection in experimental disease models. Semin Cell Dev Biol 35: 2-13, 2014.

9. Upton JW, Kaiser WJ and Mocarski ES: DAI/ZBP1/DLM-1 complexes with RIP3 to mediate virus-induced programmed necrosis that is targeted by murine cytomegalovirus vIRA. Cell Host Microbe 11: 290-297, 2012.

10. Oberst A and Green DR: It cuts both ways: Reconciling the dual roles of caspase 8 in cell death and survival. Nat Rev Mol Cell Biol 12: 757-763, 2011.

11. Kaiser WJ, Upton JW, Long AB, Livingston-Rosanoff D, Daley-Bauer LP, Hakem R, Caspary T and Mocarski ES: RIP3 mediates the embryonic lethality of caspase-8-deficient mice. Nature 471: 368-372, 2011.

12. Weinlich R, Oberst A, Beere HM and Green DR: Necroptosis in development, inflammation and disease. Nat Rev Mol Cell Biol 18: 127-136, 2017. 
13. Sun X, Yin J, Starovasnik MA, Fairbrother WJ and Dixit VM: Identification of a novel homotypic interaction motif required for the phosphorylation of receptor-interacting protein (RIP) by RIP3. J Biol Chem 277: 9505-9511, 2002.

14. Sun X, Lee J, Navas T, Baldwin DT, Stewart TA and Dixit VM: RIP3, a novel apoptosis-inducing kinase. J Biol Chem 274: 16871-16875, 1999.

15. Shan B, Pan H, Najafov A and Yuan J: Necroptosis in development and diseases. Genes Dev 32: 327-340, 2018.

16. Dillon CP, Tummers B, Baran K and Green DR: Developmental checkpoints guarded by regulated necrosis. Cell Mol Life Sci 73 2125-2136, 2016

17. Hacker G: The morphology of apoptosis. Cell Tissue Res 301: $5-17,2000$

18. Ch'en IL, Tsau JS, Molkentin JD, Komatsu M and Hedrick SM: Mechanisms of necroptosis in T cells. J Exp Med 208: 633-641, 2011.

19. Lenardo M, Chan KM, Hornung F, McFarland H, Siegel R, Wang $\mathrm{J}$ and Zheng L: Mature T lymphocyte apoptosis-immune regulation in a dynamic and unpredictable antigenic environment. Annu Rev Immunol 17: 221-253, 1999.

20. Chen D, Yu J and Zhang L: Necroptosis: An alternative cell death program defending against cancer. Biochim Biophys Acta 1865: 228-236, 2016

21. He S, Huang S and Shen Z: Biomarkers for the detection of necroptosis. Cell Mol Life Sci 73: 2177-2181, 2016.

22. Oerlemans MI, Liu J, Arslan F, den Ouden K, van Middelaar BJ Doevendans PA and Sluijter JP: Inhibition of RIP1-dependent necrosis prevents adverse cardiac remodeling after myocardia ischemia-reperfusion in vivo. Basic Res Cardiol 107: 270, 2012.

23. Dong K, Zhu H, Song Z, Gong Y, Wang F, Wang W, Zheng Z, Yu Z, Gu Q, Xu X and Sun X: Necrostatin-1 protects photoreceptors from cell death and improves functional outcome after experimental retinal detachment. Am J Pathol 181: 1634-1641, 2012.

24. McQuade T, Cho Y and Chan FK: Positive and negative phosphorylation regulates RIP1- and RIP3-induced programmed necrosis. Biochem J 456: 409-415, 2013.

25. Wang H, Sun L, Su L, Rizo J, Liu L, Wang LF, Wang FS and Wang X: Mixed lineage kinase domain-like protein MLKL causes necrotic membrane disruption upon phosphorylation by RIP3. Mol Cell 54: 133-146, 2014.

26. Li JX, Feng JM, Wang Y, Li XH, Chen XX, Su Y, Shen YY, Chen Y, Xiong B, Yang CH, et al: The B-Raf(V600E) inhibitor dabrafenib selectively inhibits RIP3 and alleviates acetaminophen-induced liver injury. Cell Death Dis 5: e1278, 2014.

27. Kaiser WJ, Sridharan H, Huang C, Mandal P, Upton JW, Gough PJ, Sehon CA, Marquis RW, Bertin J and Mocarski ES: Toll-like receptor 3-mediated necrosis via TRIF, RIP3, and MLKL. J Biol Chem 288: 31268-31279, 2013.

28. Conrad M, Angeli JP, Vandenabeele P and Stockwell BR: Regulated necrosis: Disease relevance and therapeutic opportunities. Nat Rev Drug Discov 15: 348-366, 2016.

29. Dannappel M, Vlantis K, Kumari S, Polykratis A, Kim C, Wachsmuth L, Eftychi C, Lin J, Corona T, Hermance N, et al: RIPK1 maintains epithelial homeostasis by inhibiting apoptosis and necroptosis. Nature 513: 90-94, 2014

30. Takahashi N, Vereecke L, Bertrand MJ, Duprez L, Berger SB, Divert T, Gonçalves A, Sze M, Gilbert B, Kourula S, et al: RIPK1 ensures intestinal homeostasis by protecting the epithelium against apoptosis. Nature 513: 95-99, 2014.

31. Gunther C, Martini E, Wittkopf N, Amann K, Weigmann B Neumann H, Waldner MJ, Hedrick SM, Tenzer S, Neurath MF and Becker C: Caspase- 8 regulates TNF- $\alpha$-induced epithelial necroptosis and terminal ileitis. Nature 477: 335-339, 2011

32. Wong WW, Vince JE, Lalaoui N, Lawlor KE, Chau D, Bankovacki A, Anderton H, Metcalf D, O'Reilly L, Jost PJ, et al cIAPs and XIAP regulate myelopoiesis through cytokine production in an RIPK1- and RIPK3-dependent manner. Blood 123 2562-2572, 2014

33. Roderick JE, Hermance N, Zelic M, Simmons MJ, Polykratis A, Pasparakis M and Kelliher MA: Hematopoietic RIPK1 deficiency results in bone marrow failure caused by apoptosis and RIPK3-mediated necroptosis. Proc Natl Acad Sci USA 111: 14436-14441, 2014.

34. Rickard JA, O'Donnell JA, Evans JM, Lalaoui N, Poh AR, Rogers T, Vince JE, Lawlor KE, Ninnis RL, Anderton H, et al: RIPK1 regulates RIPK3-MLKL-driven systemic inflammation and emergency hematopoiesis. Cell 157: 1175-1188, 2014.
35. Dillon CP, Weinlich R, Rodriguez DA, Cripps JG, Quarato G, Gurung P, Verbist KC, Brewer TL, Llambi F, Gong YN, et al: RIPK1 blocks early postnatal lethality mediated by caspase- 8 and RIPK3. Cell 157: 1189-1202, 2014.

36. Oberst A, Dillon CP, Weinlich R, McCormick LL, Fitzgerald P, Pop C, Hakem R, Salvesen GS and Green DR: Catalytic activity of the caspase-8-FLIP(L) complex inhibits RIPK3-dependent necrosis. Nature 471: 363-367, 2011.

37. Matsuoka Y and Tsujimoto Y: Role of RIP1 in physiological enterocyte turnover in mouse small intestine via nonapoptotic death. Genes Cells 20: 11-28, 2015.

38. Huang Z, Wu SQ, Liang Y, Zhou X, Chen W, Li L, Wu J, Zhuang Q, Chen C, Li J, et al: RIP1/RIP3 binding to HSV-1 ICP6 initiates necroptosis to restrict virus propagation in mice. Cell Host Microbe 17: 229-242, 2015.

39. Omoto S, Guo H, Talekar GR, Roback L, Kaiser WJ and Mocarski ES: Suppression of RIP3-dependent necroptosis by human cytomegalovirus. J Biol Chem 290: 11635-11648, 2015.

40. Nogusa S, Thapa RJ, Dillon CP, Liedmann S, Oguin TH III, Ingram JP, Rodriguez DA, Kosoff R, Sharma S, Sturm O, et al: RIPK 3 activates parallel pathways of MLKL-Driven necroptosis and FADD-Mediated apoptosis to protect against influenza a virus. Cell Host Microbe 20: 13-24, 2016.

41. Pearson JS, Giogha C, Ong SY, Kennedy CL, Kelly M, Robinson KS, Lung TW, Mansell A, Riedmaier P, Oates CV, et al: A type III effector antagonizes death receptor signalling during bacterial gut infection. Nature 501: 247-251, 2013.

42. Li S, Zhang L, Yao Q, Li L, Dong N, Rong J, Gao W, Ding X, Sun L, Chen X, et al: Pathogen blocks host death receptor signalling by arginine GlcNAcylation of death domains. Nature 501: 242-246, 2013

43. Weng D, Marty-Roix R, Ganesan S, Proulx MK, Vladimer GI, Kaiser WJ, Mocarski ES, Pouliot K, Chan FK, Kelliher MA, et al: Caspase- 8 and RIP kinases regulate bacteria-induced innate immune responses and cell death. Proc Natl Acad Sci USA 111: 7391-7396, 2014

44. Philip NH, Dillon CP, Snyder AG, Fitzgerald P, Wynosky-Dolfi MA, Zwack EE, Hu B, Fitzgerald L, Mauldin EA, Copenhaver AM, et al: Caspase-8 mediates caspase-1 processing and innate immune defense in response to bacterial blockade of NF- $\kappa$ B and MAPK signaling. Proc Natl Acad Sci USA 111: 7385-7390, 2014.

45. Robinson N, McComb S, Mulligan R, Dudani R, Krishnan L and Sad S: Type I interferon induces necroptosis in macrophages during infection with Salmonella enterica serovar Typhimurium. Nat Immunol 13: 954-962, 2012.

46. Bleriot $C$ and Lecuit $M$ : The interplay between regulated necrosis and bacterial infection. Cell Mol Life Sci 73: 2369-2378, 2016.

47. Hu GQ, Yang YJ, Qin XX, Qi S, Zhang J, Yu SX, Du CT and Chen W: Salmonella outer protein B suppresses colitis development via protecting cell from necroptosis. Front Cell Infect Microbiol 9: 87, 2019.

48. Fortes GB, Alves LS, de Oliveira R, Dutra FF, Rodrigues D, Fernandez PL, Souto-Padron T, De Rosa MJ, Kelliher M, Golenbock D, et al: Heme induces programmed necrosis on macrophages through autocrine TNF and ROS production. Blood 119: 2368-2375, 2012.

49. Yao Y, Liu M, Ren C, Shen J and Ji Y: Exogenous tumor necrosis factor-alpha could induce egress of Toxoplasma gondii from human foreskin fibroblast cells. Parasite 24: 45, 2017.

50. Liu Y, Liu T, Lei T, Zhang D, Du S, Girani L, Qi D, Lin C, Tong R and Wang Y: RIP1/RIP3-regulated necroptosis as a target for multifaceted disease therapy (Review). Int J Mol Med 44: 771-786, 2019.

51. Koo GB, Morgan MJ, Lee DG, Kim WJ, Yoon JH, Koo JS, Kim SI, Kim SJ, Son MK, Hong SS, et al: Methylation-dependent loss of RIP3 expression in cancer represses programmed necrosis in response to chemotherapeutics. Cell Res 25: 707-725, 2015.

52. Stoll G, Ma Y, Yang H, Kepp O, Zitvogel L and Kroemer G: Pro-necrotic molecules impact local immunosurveillance in human breast cancer. Oncoimmunology 6: e1299302, 2017.

53. Feng $X$, Song Q, Yu A, Tang $H$, Peng $Z$ and Wang $X$ : Receptor-interacting protein kinase 3 is a predictor of survival and plays a tumor suppressive role in colorectal cancer. Neoplasma 62: 592-601, 2015.

54. Moriwaki K, Bertin J, Gough PJ, Orlowski GM and Chan FK: Differential roles of RIPK1 and RIPK3 in TNF-induced necroptosis and chemotherapeutic agent-induced cell death. Cell Death Dis 6: e1636, 2015 
55. Li X, Guo J, Ding AP, Qi WW, Zhang PH, Lv J, Qiu WS and Sun ZQ: Association of mixed lineage kinase domain-like protein expression with prognosis in patients with colon cancer. Technol Cancer Res Treat 16: 428-434, 2017.

56. Nugues AL, El Bouazzati H, Hetuin D, Berthon C, Loyens A, Bertrand E, Jouy N, Idziorek T and Quesnel B: RIP3 is downregulated in human myeloid leukemia cells and modulates apoptosis and caspase-mediated p65/RelA cleavage. Cell Death Dis 5: e1384, 2014.

57. Hockendorf U, Yabal M, Herold T, Munkhbaatar E, Rott S, Jilg S, Kauschinger J, Magnani G, Reisinger F, Heuser M, et al: RIPK3 restricts myeloid leukemogenesis by promoting cell death and differentiation of leukemia initiating cells. Cancer Cell 30: 75-91, 2016.

58. Geserick P, Wang J, Schilling R, Horn S, Harris PA, Bertin J, Gough PJ, Feoktistova M and Leverkus M: Absence of RIPK3 predicts necroptosis resistance in malignant melanoma. Cell Death Dis 6: e1884, 2015.

59. Ke H, Augustine CK, Gandham VD, Jin JY, Tyler DS, Akiyama SK, Hall RP and Zhang JY: CYLD inhibits melanoma growth and progression through suppression of the JNK/AP-1 and betal-integrin signaling pathways. J Invest Dermatol 133: 221-229, 2013

60. McCormick KD, Ghosh A, Trivedi S, Wang L, Coyne CB, Ferris RL and Sarkar SN: Innate immune signaling through differential RIPK1 expression promote tumor progression in head and neck squamous cell carcinoma. Carcinogenesis 37: 522-529, 2016

61. Ertao Z, Jianhui C, Kang W, Zhijun Y, Hui W, Chuangqi C, Changjiang Q, Sile C, Yulong $\mathrm{H}$ and Shirong C: Prognostic value of mixed lineage kinase domain-like protein expression in the survival of patients with gastric caner. Tumour Biol 37: 13679-13685, 2016

62. He L, Peng K, Liu Y, Xiong J and Zhu FF: Low expression of mixed lineage kinase domain-like protein is associated with poor prognosis in ovarian cancer patients. Onco Targets Ther 6 : $1539-1543,2013$

63. Ruan J, Mei L, Zhu Q, Shi G and Wang H: Mixed lineage kinase domain-like protein is a prognostic biomarker for cervical squamous cell cancer. Int J Clin Exp Pathol 8: 15035-15038, 2015.

64. Park S, Hatanpaa KJ,Xie Y,Mickey BE, Madden CJ, Raisanen JM, Ramnarain DB, Xiao G, Saha D, Boothman DA, et al: The receptor interacting protein 1 inhibits p53 induction through NF-kappaB activation and confers a worse prognosis in glioblastoma. Cancer Res 69: 2809-2816, 2009.

65. Wang Q, Chen W, Xu X, Li B, He W, Padilla MT, Jang JH, Nyunoya T, Amin S, Wang X and Lin Y: RIP1 potentiates BPDE-induced transformation in human bronchial epithelia cells through catalase-mediated suppression of excessive reactive oxygen species. Carcinogenesis 34: 2119-2128, 2013.

66. Seifert L, Werba G, Tiwari S, Giao Ly NN, Alothman S, Alqunaibit D, Avanzi A, Barilla R, Daley D, Greco SH, et al: The necrosome promotes pancreatic oncogenesis via CXCL1 and Mincle-induced immune suppression. Nature 532: 245-249, 2016

67. Colbert LE, Fisher SB, Hardy CW, Hall WA, Saka B, Shelton JW, Petrova AV, Warren MD, Pantazides BG, Gandhi K, et al: Pronecrotic mixed lineage kinase domain-like protein expression is a prognostic biomarker in patients with early-stage resected pancreatic adenocarcinoma. Cancer 119: 3148-3155, 2013

68. Cabal-Hierro L and O'Dwyer PJ: TNF signaling through RIP1 kinase enhances SN38-Induced death in colon adenocarcinoma. Mol Cancer Res 15: 395-404, 2017.

69. Wu Y and Zhou BP: Inflammation: A driving force speeds cancer metastasis. Cell Cycle 8: 3267-3273, 2009.

70. Liu ZY, Wu B, Guo YS, Zhou YH, Fu ZG, Xu BQ, Li JH, Jing L, Jiang JL, Tang J and Chen ZN: Necrostatin-1 reduces intestinal inflammation and colitis-associated tumorigenesis in mice. Am J Cancer Res 5: 3174-3185, 2015.

71. Exner N, Lutz AK, Haass C and Winklhofer KF: Mitochondrial dysfunction in Parkinson's disease: Molecular mechanisms and pathophysiological consequences. EMBO J 31: 3038-3062, 2012.

72. Iannielli A, Bido S, Folladori L, Segnali A, Cancellieri C, Maresca A, Massimino L, Rubio A, Morabito G, Caporali L, et al: Pharmacological inhibition of necroptosis protects from dopaminergic neuronal cell death in Parkinson's disease models. Cell Rep 22: 2066-2079, 2018

73. Wu JR, Wang J, Zhou SK, Yang L, Yin JL, Cao JP and Cheng YB Necrostatin-1 protection of dopaminergic neurons. Neural Regen Res 10: 1120-1124, 2015 .
74. Amin P, Florez M, Najafov A, Pan H, Geng J, Ofengeim D, Dziedzic SA, Wang H, Barrett VJ, Ito Y, et al: Regulation of a distinct activated RIPK1 intermediate bridging complex I and complex II in TNFalpha-mediated apoptosis. Proc Natl Acad Sci USA 115: E5944-E5953, 2018.

75. Caccamo A, Branca C, Piras IS, Ferreira E, Huentelman MJ, Liang WS, Readhead B, Dudley JT, Spangenberg EE, Green KN, et al: Necroptosis activation in Alzheimer's disease. Nat Neurosci 20: 1236-1246, 2017.

76. Ofengeim D, Mazzitelli S, Ito Y, DeWitt JP, Mifflin L, Zou C, Das S, Adiconis X, Chen $\mathrm{H}$, Zhu H, et al: RIPK1 mediates a disease-associated microglial response in Alzheimer's disease. Proc Natl Acad Sci USA 114: E8788-E8797, 2017.

77. Ito Y, Ofengeim D, Najafov A, Das S, Saberi S, Li Y, Hitomi J, Zhu H, Chen H, Mayo L, et al: RIPK1 mediates axonal degeneration by promoting inflammation and necroptosis in ALS Science 353: 603-608, 2016.

78. Ofengeim D, Ito Y, Najafov A, Zhang Y, Shan B, DeWitt JP Ye J, Zhang X, Chang A, Vakifahmetoglu-Norberg $\mathrm{H}$, et al: Activation of necroptosis in multiple sclerosis. Cell Rep 10: 1836-1849, 2015

79. Zhang S, Su Y, Ying Z, Guo D, Pan C, Guo J, Zou Z, Wang L, Zhang Z, Jiang Z, et al: RIP1 kinase inhibitor halts the progression of an immune-induced demyelination disease at the stage of monocyte elevation. Proc Natl Acad Sci USA 116: 5675-5680, 2019.

80. Roychowdhury S, McCullough RL, Sanz-Garcia C, Saikia P, Alkhouri N, Matloob A, Pollard KA, McMullen MR, Croniger CM and Nagy LE: Receptor interacting protein 3 protects mice from high-fat diet-induced liver injury. Hepatology 64: 1518-1533, 2016.

81. Xu H, Du X, Liu G, Huang S, Du W, Zou S, Tang D, Fan C, Xie Y, Wei Y, et al: The pseudokinase MLKL regulates hepatic insulin sensitivity independently of inflammation. Mol Metab 23: 14-23, 2019.

82. Saeed WK, Jun DW, Jang K, Ahn SB, Oh JH, Chae YJ, Lee JS and Kang HT: Mismatched effects of receptor interacting protein kinase-3 on hepatic steatosis and inflammation in non-alcoholic fatty liver disease. World J Gastroenterol 24: 5477-5490, 2018

83. Gautheron J, Vucur M, Reisinger F, Cardenas DV, Roderburg C, Koppe C, Kreggenwinkel K, Schneider AT, Bartneck M, Neumann UP, et al: A positive feedback loop between RIP3 and JNK controls non-alcoholic steatohepatitis. EMBO Mol Med 6: 1062-1074, 2014

84. Gautheron J, Vucur M, Schneider AT, Severi I, Roderburg C, Roy S, Bartneck M, Schrammen P, Diaz MB, Ehling J, et al: The necroptosis-inducing kinase RIPK3 dampens adipose tissue inflammation and glucose intolerance. Nat Commun 7: 11869, 2016.

85. Afonso MB, Rodrigues PM, Carvalho T, Caridade M, Borralho P, Cortez-Pinto H, Castro RE and Rodrigues CM: Necroptosis is a key pathogenic event in human and experimental murine models of non-alcoholic steatohepatitis. Clin Sci (Lond) 129: 721-739, 2015.

86. Roychowdhury S, McMullen MR, Pisano SG, Liu X and Nagy LE: Absence of receptor interacting protein kinase 3 prevents ethanol-induced liver injury. Hepatology 57: 1773-1783, 2013.

87. Wang S, Ni HM, Dorko K, Kumer SC, Schmitt TM, Nawabi A, Komatsu M, Huang H and Ding WX: Increased hepatic receptor interacting protein kinase 3 expression due to impaired proteasomal functions contributes to alcohol-induced steatosis and liver injury. Oncotarget 7: 17681-17698, 2016.

88. Jia Y, Wang F, Guo Q, Li M, Wang L, Zhang Z, Jiang S, Jin H, Chen A, Tan S, et al: Curcumol induces RIPK1/RIPK3 complex-dependent necroptosis via JNK1/2-ROS signaling in hepatic stellate cells. Redox Biol 19: 375-387, 2018.

89. Dal-Re R: Worldwide behavioral research on major global causes of mortality. Health Educ Behav 38: 433-440, 2011.

90. Mizumura K, Cloonan SM, Nakahira K, Bhashyam AR, Cervo M, Kitada T, Glass K, Owen CA, Mahmood A, Washko GR, et al: Mitophagy-dependent necroptosis contributes to the pathogenesis of COPD. J Clin Invest 124: 3987-4003, 2014.

91. Pouwels SD, Zijlstra GJ, van der Toorn M, Hesse L, Gras R, Ten Hacken NH, Krysko DV, Vandenabeele P, de Vries M, van Oosterhout AJ, et al: Cigarette smoke-induced necroptosis and DAMP release trigger neutrophilic airway inflammation in mice. Am J Physiol Lung Cell Mol Physiol 310: L377-L386, 2016. 
92. Wang Y, Zhou JS, Xu XC, Li ZY, Chen HP, Ying SM, Li W, Shen $\mathrm{HH}$ and Chen $\mathrm{ZH}$ : Endoplasmic reticulum chaperone GRP78 mediates cigarette smoke-induced necroptosis and injury in bronchial epithelium. Int J Chron Obstruct Pulmon Dis 13: 571-581, 2018.

93. Rubenfeld GD, Caldwell E, Peabody E, Weaver J, Martin DP, Neff M, Stern EJ and Hudson LD: Incidence and outcomes of acute lung injury. N Engl J Med 353: 1685-1693, 2005.

94. Syed MA, Shah D, Das P, Andersson S, Pryhuber G and Bhandari V: TREM-1 Attenuates RIPK3-mediated necroptosis in hyperoxia-induced lung injury in neonatal mice. Am J Respir Cell Mol Biol 60: 308-322, 2019.

95. Chen J, Wang S, Fu R, Zhou M, Zhang T, Pan W, Yang N and Huang Y: RIP3 dependent NLRP3 inflammasome activation is implicated in acute lung injury in mice. J Transl Med 16: 233, 2018.

96. Siempos II, Ma KC, Imamura M, Baron RM, Fredenburgh LE, Huh JW, Moon JS, Finkelsztein EJ, Jones DS, Lizardi MT, et al: RIPK3 mediates pathogenesis of experimental ventilator-induced lung injury. JCI Insight 3: e97102, 2018.

97. Bolognese AC, Yang WL, Hansen LW, Denning NL, Nicastro JM, Coppa GF and Wang P: Inhibition of necroptosis attenuates lung injury and improves survival in neonatal sepsis. Surgery: Apr 27, 2018 (Epub ahead of print).

98. Kobayashi K, Araya J, Minagawa S, Hara H, Saito N, Kadota T, Sato N, Yoshida M, Tsubouchi K, Kurita Y, et al: Involvement of PARK2-mediated mitophagy in idiopathic pulmonary fibrosis pathogenesis. J Immunol 197: 504-516, 2016.

99. Lee JM, Yoshida M, Kim MS, Lee JH, Baek AR, Jang AS, Kim DJ, Minagawa S, Chin SS, Park CS, et al: Involvement of alveolar epithelial cell necroptosis in idiopathic pulmonary fibrosis pathogenesis. Am J Respir Cell Mol Biol 59: 215-224, 2018.

100.Papi A, Brightling C, Pedersen SE and Reddel HK: Asthma. Lancet 391: 783-800, 2018.

101. Cerps SC, Menzel M, Mahmutovic Persson I, Bjermer L, Akbarshahi $\mathrm{H}$ and Uller L: Interferon-beta deficiency at asthma exacerbation promotes MLKL mediated necroptosis. Sci Rep 8 : $4248,2018$.

102. Shlomovitz I, Erlich Z, Speir M, Zargarian S, Baram N, Engler M, Edry-Botzer L, Munitz A, Croker BA and Gerlic M: Necroptosis directly induces the release of full-length biologically active IL-33 in vitro and in an inflammatory disease model. FEBS J 286: 507-522, 2019.

103. Zhang H, Ji J, Liu Q and Xu S: MUC1 downregulation promotes TNF- $\alpha$-induced necroptosis in human bronchial epithelial cells via regulation of the RIPK1/RIPK3 pathway. J Cell Physiol 234 $15080-15088,2019$

104. Linkermann A, Brasen JH, Darding M, Jin MK, Sanz AB, Heller JO, De Zen F, Weinlich R, Ortiz A, Walczak H, et al Two independent pathways of regulated necrosis mediate ischemia-reperfusion injury. Proc Natl Acad Sci USA 110 12024-12029, 2013

105. Linkermann A, Skouta R, Himmerkus N, Mulay SR, Dewitz C, De Zen F, Prokai A, Zuchtriegel G, Krombach F, Welz PS, et al: Synchronized renal tubular cell death involves ferroptosis. Proc Natl Acad Sci USA 111: 16836-16841, 2014.

106.Linkermann A, Brasen JH, Himmerkus N, Liu S, Huber TB, Kunzendorf U and Krautwald S: Rip1 (receptor-interacting protein kinase 1) mediates necroptosis and contributes to renal ischemia/reperfusion injury. Kidney Int 81: 751-761, 2012

107. Mulay SR, Desai J, Kumar SV, Eberhard JN, Thomasova D, Romoli S, Grigorescu M, Kulkarni OP, Popper B, Vielhauer V, et al: Cytotoxicity of crystals involves RIPK3-MLKL-mediated necroptosis. Nat Commun 7: 10274, 2016.

108. Tristao VR, Goncalves PF, Dalboni MA, Batista MC, Durao Mde S Jr and Monte JC: Nec-1 protects against nonapoptotic cell death in cisplatin-induced kidney injury. Ren Fail 34 373-377, 2012

109. Linkermann A, Heller JO, Prokai A, Weinberg JM, De Zen F, Himmerkus N, Szabó AJ, Bräsen JH, Kunzendorf U and Krautwald S: The RIP1-kinase inhibitor necrostatin-1 prevents osmotic nephrosis and contrast-induced AKI in mice. J Am Soc Nephrol 24: 1545-1557, 2013.

110. Xu Y, Ma H, Shao J, Wu J, Zhou L, Zhang Z, Wang Y, Huang Z, Ren J, Liu S, et al: A role for tubular necroptosis in Cisplatin-Induced AKI. J Am Soc Nephrol 26: 2647-2658, 2015.
111. Tristao VR, Pessoa EA, Nakamichi R, Reis LA, Batista MC, Durão Junior Mde S and Monte JC: Synergistic effect of apoptosis and necroptosis inhibitors in cisplatin-induced nephrotoxicity. Apoptosis 21: 51-59, 2016.

112. Zhu Y, Cui H, Gan H, Xia Y, Wang L, Wang Y and Sun Y: Necroptosis mediated by receptor interaction protein kinase 1 and 3 aggravates chronic kidney injury of subtotal nephrectomised rats. Biochem Biophys Res Commun 461: 575-581, 2015.

113. Chen H, Fang Y, Wu J, Chen H, Zou Z, Zhang X, Shao J and $\mathrm{Xu}$ Y: RIPK3-MLKL-mediated necroinflammation contributes to AKI progression to CKD. Cell Death Dis 9: 878, 2018.

114. McManus DD, Piacentine SM, Lessard D, Gore JM, Yarzebski J, Spencer FA and Goldberg RJ: Thirty-year (1975 to 2005) trends in the incidence rates, clinical features, treatment practices, and short-term outcomes of patients $<55$ years of age hospitalized with an initial acute myocardial infarction. Am J Cardiol 108: 477-482, 2011.

115. Luedde M, Lutz M, Carter N, Sosna J, Jacoby C, Vucur M, Gautheron J, Roderburg C, Borg N, Reisinger F, et al: RIP3, a kinase promoting necroptotic cell death, mediates adverse remodelling after myocardial infarction. Cardiovasc Res 103: 206-216, 2014

116. Zhang T, Zhang Y, Cui M, Jin L, Wang Y, Lv F, Liu Y, Zheng W, Shang $\mathrm{H}$, Zhang J, et al: CaMKII is a RIP3 substrate mediating ischemia- and oxidative stress-induced myocardial necroptosis. Nat Med 22: 175-182, 2016.

117. Lusis AJ: Atherosclerosis. Nature 407: 233-241, 2000.

118. Karunakaran D, Geoffrion M, Wei L, Gan W, Richards L, Shangari P, DeKemp EM, Beanlands RA, Perisic L, Maegdefessel L, et al: Targeting macrophage necroptosis for therapeutic and diagnostic interventions in atherosclerosis. Sci Adv 2: e1600224, 2016

119. Henderson B, Revell PA and Edwards JC: Synovial lining cell hyperplasia in rheumatoid arthritis: Dogma and fact. Ann Rheum Dis 47: 348-349, 1988.

120. Lee SH, Kwon JY, Kim SY, Jung K and Cho ML: Interferon-gamma regulates inflammatory cell death by targeting necroptosis in experimental autoimmune arthritis. Sci Rep 7: 10133, 2017

121. Jhun J, Lee SH, Kim SY, Ryu J, Kwon JY, Na HS, Jung K, Moon SJ, Cho ML and Min JK: RIPK1 inhibition attenuates experimental autoimmune arthritis via suppression of osteoclastogenesis. J Transl Med 17: 84, 2019.

122. Glyn-Jones S, Palmer AJ, Agricola R, Price AJ, Vincent TL, Weinans H and Carr AJ: Osteoarthritis. Lancet 386: 376-387, 2015.

123. Riegger J and Brenner RE: Evidence of necroptosis in osteoarthritic disease: Investigation of blunt mechanical impact as possible trigger in regulated necrosis. Cell Death Dis 10: 683, 2019

124. Galluzzi L, Kepp O, Chan FK and Kroemer G: Necroptosis: Mechanisms and relevance to disease. Annu Rev Pathol 12: 103-130, 2017.

125. Della Torre L, Nebbioso A, Stunnenberg HG, Martens JHA, Carafa V and Altucci L: The role of necroptosis: Biological relevance and its involvement in cancer. Cancers (Basel) 13: 684, 2021.

126. Martens S, Hofmans S, Declercq W, Augustyns K and Vandenabeele P: Inhibitors Targeting RIPK1/RIPK3: Old and new drugs. Trends Pharmacol Sci 41: 209-224, 2020.

127. Thapa RJ, Nogusa S, Chen P, Maki JL, Lerro A, Andrake M, Rall GF, Degterev A and Balachandran S: Interferon-induced RIP1/RIP3-mediated necrosis requires PKR and is licensed by FADD and caspases. Proc Natl Acad Sci USA 110: E3109-E3118, 2013.

128. Bollino D, Balan I and Aurelian L: Valproic acid induces neuronal cell death through a novel calpain-dependent necroptosis pathway. J Neurochem 133: 174-186, 2015.

129. Kim HJ, Hwang KE, Park DS, Oh SH, Jun HY, Yoon KH, Jeong ET, Kim HR and Kim YS: Shikonin-induced necroptosis is enhanced by the inhibition of autophagy in non-small cell lung cancer cells. J Transl Med 15: 123, 2017.

130. Zhou J, Li G, Han G, Feng S, Liu Y, Chen J, Liu C, Zhao L and Jin F: Emodin induced necroptosis in the glioma cell line U251 via the TNF- $\alpha /$ RIP1/RIP3 pathway. Invest New Drugs 38: 50-59, 2020

131. Li Y, Tian X, Liu X and Gong P: Bufalin inhibits human breast cancer tumorigenesis by inducing cell death through the ROS-mediated RIP1/RIP3/PARP-1 pathways. Carcinogenesis 39: 700-707, 2018. 
132. Han Q, Ma Y, Wang H, Dai Y, Chen C, Liu Y, Jing L and Sun X: Resibufogenin suppresses colorectal cancer growth and metastasis through RIP3-mediated necroptosis. J Transl Med 16: 201, 2018

133. Fakharnia F, Khodagholi F, Dargahi L and Ahmadiani A: Prevention of Cyclophilin D-Mediated mPTP Opening Using Cyclosporine-A Alleviates the Elevation of Necroptosis, Autophagy and Apoptosis-Related Markers Following Global Cerebral Ischemia-Reperfusion. J Mol Neurosci 61: 52-60, 2017.

134. Ding J, Yang N, Yan Y, Wang Y, Wang X, Lu L and Dong K: Rapamycin inhibited photoreceptor necroptosis and protected the retina by activation of autophagy in experimental retinal detachment. Curr Eye Res 44: 739-745, 2019.

135. Yan C, Oh JS, Yoo SH, Lee JS, Yoon YG, Oh YJ, Jang MS Lee SY, Yang J and Lee SH, et al: The targeted inhibition of mitochondrial Hsp90 overcomes the apoptosis resistance conferred by Bcl-2 in Hep3B cells via necroptosis. Toxicol App Pharmacol 266: 9-18, 2013.

136. Li D, Li C, Li L, Chen S, Wang L, Li Q, Wang X, Lei X and Shen Z: Natural Product Kongensin A is a Non-Canonical HSP90 Inhibitor that Blocks RIP3-dependent Necroptosis. Cell Chem Biol 23: 257-266, 2016.

137. Zhang Z, Li HM, Zhou C, Li Q, Ma L, Zhang Z, Sun Y, Wang L, Zhang $\mathrm{X}$, Zhu B, et al: Non-benzoquinone geldanamycin analogs trigger various forms of death in human breast cancer cells. J Exp Clin Cancer Res 35: 149, 2016.

138. Chen WW, Yu H, Fan HB, Zhang CC, Zhang M, Zhang C, Cheng Y, Kong J, Liu CF, Geng D and Xu X: RIP1 mediates the protection of geldanamycin on neuronal injury induced by oxygen-glucose deprivation combined with zVAD in primary cortical neurons. J Neurochem 120: 70-77, 2012.

139. Qu C, Yuan ZW, Yu XT, Huang YF, Yang GH, Chen JN, Lai XP, Su ZR, Zeng HF, Xie Y and Zhang XJ: Patchouli alcohol ameliorates dextran sodium sulfate-induced experimental colitis and suppresses tryptophan catabolism. Pharmacol Res 121: 70-82, 2017.

140. Fauster A, Rebsamen M, Huber KV, Bigenzahn JW, Stukalov A, Lardeau CH, Scorzoni S, Bruckner M, Gridling M, Parapatics K, et al: A cellular screen identifies ponatinib and pazopanib as inhibitors of necroptosis. Cell Death Dis 6: e1767, 2015.

141. Harris PA, Marinis JM, Lich JD, Berger SB, Chirala A, Cox JA, Eidam PM, Finger JN, Gough PJ, Jeong JU, et al: Identification of a RIP1 Kinase Inhibitor Clinical Candidate (GSK3145095) for the treatment of pancreatic cancer. ACS Med Chem Lett 10: $857-862,2019$

142. Ali M and Mocarski ES: Proteasome inhibition blocks necroptosis by attenuating death complex aggregation. Cell Death Dis 9: 346, 2018.

143. Martens S, Jeong M, Tonnus W, Feldmann F, Hofmans S, Goossens V, Takahashi N, Bräsen JH, Lee EW, Van der Veken P, et al: Sorafenib tosylate inhibits directly necrosome complex formation and protects in mouse models of inflammation and tissue injury. Cell Death Dis 8: e2904, 2017.

144. von Mässenhausen A, Tonnus W, Himmerkus N, Parmentier S, Saleh D, Rodriguez D, Ousingsawat J, Ang RL, Weinberg JM, Sanz AB, et al: Phenytoin inhibits necroptosis. Cell Death Dis 9: 359,2018

145. Wang J, Li Y, Huang WH, Zeng XC, Li XH, Li J, Zhou J, Xiao J, Xiao B, Ouyang DS and Hu K: The protective effect of aucubin from eucommia ulmoides against status epilepticus by inducing autophagy and inhibiting necroptosis. Am J Chin Med 45: $557-573,2017$

146. Meng XM, Li HD, Wu WF, Ming-Kuen Tang P, Ren GL, Gao L, Li XF, Yang Y, Xu T, Ma TT, et al: Wogonin protects against cisplatin-induced acute kidney injury by targeting RIPK1-mediated necroptosis. Lab Invest 98: 79-94, 2018.

147. Nehs MA, Lin CI, Kozono DE, Whang EE, Cho NL, Zhu K, Moalem J, Moore FD Jr and Ruan DT: Necroptosis is a novel mechanism of radiation-induced cell death in anaplastic thyroid and adrenocortical cancers. Surgery 150: 1032-1039, 2011

148. Oliver Metzig M, Fuchs D, Tagscherer KE, Gröne HJ, Schirmacher P and Roth W: Inhibition of caspases primes colon cancer cells for 5 -fluorouracil-induced TNF- $\alpha$-dependent necroptosis driven by RIP1 kinase and NF-кB. Oncogene 35: 3399-3409, 2016
149. Choi MJ, Kang H, Lee YY, Choo OS, Jang JH, Park SH, Moon JS, Choi SJ and Choung YH: Cisplatin-Induced ototoxicity in rats is driven by RIP3-Dependent necroptosis. Cells 8: 409, 2019.

150. Yang H, Ma Y, Chen G, Zhou H, Yamazaki T, Klein C, Pietrocola F, Vacchelli E, Souquere S, Sauvat A, et al: Contribution of RIP3 and MLKL to immunogenic cell death signaling in cancer chemotherapy. Oncoimmunology 5: el149673, 2016.

151. Basit F, Cristofanon S and Fulda S: Obatoclax (GX15-070) triggers necroptosis by promoting the assembly of the necrosome on autophagosomal membranes. Cell Death Differ 20: 1161-1173, 2013.

152. Deng Q, Yu X, Xiao L, Hu Z, Luo X, Tao Y, Yang L, Liu X, Chen $\mathrm{H}$, Ding Z, et al: Neoalbaconol induces energy depletion and multiple cell death in cancer cells by targeting PDK1-PI3-K/Akt signaling pathway. Cell Death Dis 4: e804, 2013.

153. Lin CY, Chang TW, Hsieh WH, Hung MC, Lin IH, Lai SC and Tzeng YJ: Simultaneous induction of apoptosis and necroptosis by Tanshinone IIA in human hepatocellular carcinoma HepG2 cells. Cell Death Discov 2: 16065, 2016.

154. Tang D, Kang R, Berghe TV, Vandenabeele P and Kroemer G: The molecular machinery of regulated cell death. Cell Res 29: 347-364, 2019

155. Grootjans S, Vanden Berghe T and Vandenabeele P: Initiation and execution mechanisms of necroptosis: An overview. Cell Death Differ 24: 1184-1195, 2017.

156. Upton JW, Kaiser WJ and Mocarski ES: Virus inhibition of RIP3-dependent necrosis. Cell Host Microbe 7: 302-313, 2010.

157. Pan T, Wu S, He X, Luo H, Zhang Y, Fan M, Geng G, Ruiz VC Zhang J, Mills L, et al: Necroptosis takes place in human immunodeficiency virus type-1 (HIV-1)-infected CD4+ T lymphocytes. PLoS One 9: e93944, 2014.

158. Berger AK and Danthi P: Reovirus activates a caspase-independent cell death pathway. mBio 4: e00178-00113, 2013

159. Chan FK, Shisler J, Bixby JG, Felices M, Zheng L, Appel M, Orenstein J, Moss B and Lenardo MJ: A role for tumor necrosis factor receptor-2 and receptor-interacting protein in programmed necrosis and antiviral responses. J Biol Chem 278: 51613-51621, 2003.

160. Shrestha A, Mehdizadeh Gohari I and McClane BA: RIP1, RIP3, and MLKL contribute to cell death caused by clostridium perfringens enterotoxin. mBio 10: e02985-19, 2019.

161. Roca FJ and Ramakrishnan L: TNF dually mediates resistance and susceptibility to mycobacteria via mitochondrial reactive oxygen species. Cell 153: 521-534, 2013.

162. Kitur K, Parker D, Nieto P, Ahn DS, Cohen TS, Chung S, Wachtel S, Bueno S and Prince A: Toxin-induced necroptosis is a major mechanism of Staphylococcus aureus lung damage. PLoS Pathog 11: e1004820, 2015.

163. Roychowdhury S, Chiang DJ, Mandal P, McMullen MR, Liu X, Cohen JI, Pollard J, Feldstein AE and Nagy LE: Inhibition of apoptosis protects mice from ethanol-mediated acceleration of early markers of CCl4-induced fibrosis but not steatosis or inflammation. Alcohol Clin Exp Res 36: 1139-1147, 2012

164. Lu C, Xu W, Zhang F, Shao J and Zheng S: Nrf2 knockdown disrupts the protective effect of curcumin on alcohol-induced hepatocyte necroptosis. Mol Pharm 13: 4043-4053, 2016.

165. Afonso MB, Rodrigues PM, Simao AL, Ofengeim D, Carvalho T, Amaral JD, Gaspar MM, Cortez-Pinto H, Castro RE, Yuan J and Rodrigues CM: Activation of necroptosis in human and experimental cholestasis. Cell Death Dis 7: e2390, 2016.

166. Choi HS, Kang JW and Lee SM: Melatonin attenuates carbon tetrachloride-induced liver fibrosis via inhibition of necroptosis. Transl Res 166: 292-303, 2015

167. Harris PA, Berger SB, Jeong JU, Nagilla R, Bandyopadhyay D, Campobasso N, Capriotti CA, Cox JA, Dare L, Dong X, et al: Discovery of a First-in-Class receptor interacting protein 1 (RIP1) kinase specific clinical candidate (GSK2982772) for the treatment of inflammatory diseases. J Med Chem 60: 1247-1261, 2017.

This work is licensed under a Creative Commons Attribution-NonCommercial-NoDerivatives 4.0 International (CC BY-NC-ND 4.0) License. 